\title{
Engineering Nanostructured Antimony-Based Anode Materials for Sodium Ion Batteries
}

\author{
Wen Luo ${ }^{1,2, *(\mathbb{D}}$, Jingke Ren ${ }^{2}(\mathbb{D})$, Wencong Feng ${ }^{2}$, Xingbao Chen ${ }^{2}$, Yinuo Yan ${ }^{1}$ and Noura Zahir ${ }^{3}(\mathbb{D}$ \\ 1 Department of Physics, School of Science, Wuhan University of Technology, Wuhan 430070, China; \\ yanyinuo@whut.edu.cn \\ 2 School of Materials Science and Engineering, Wuhan University of Technology, Wuhan 430070, China; \\ renjingke518@163.com (J.R.); 13035889735@163.com (W.F.); a13197472368cxb@whut.com (X.C.) \\ 3 Laboratory of Chemistry and Physics-Multi-Scale Approach of Complex Media (LCP-A2MC), Université de \\ Lorraine, CNRS, L2CM, UMR 70531 bld Arago, F-57070 Metz, France; noura.zahir6@etu.univ-lorraine.fr \\ * Correspondence: luowen_1991@whut.edu.cn
}

Citation: Luo, W.; Ren, J.; Feng, W.; Chen, X.; Yan, Y.; Zahir, N.

Engineering Nanostructured Antimony-Based Anode Materials for Sodium Ion Batteries. Coatings 2021 11, 1233. https://doi.org/10.3390/ coatings11101233

Academic Editor: Claudio Mele

Received: 15 September 2021

Accepted: 8 October 2021

Published: 11 October 2021

Publisher's Note: MDPI stays neutral with regard to jurisdictional claims in published maps and institutional affiliations.

Copyright: (c) 2021 by the authors. Licensee MDPI, Basel, Switzerland. This article is an open access article distributed under the terms and conditions of the Creative Commons Attribution (CC BY) license (https:/ / creativecommons.org/licenses/by/ $4.0 /)$

\begin{abstract}
Sodium-ion batteries (SIBs) are considered a potential alternative to lithium-ion batteries (LIBs) for energy storage due to their low cost and the large abundance of sodium resources. The search for new anode materials for SIBs has become a vital approach to satisfying the ever-growing demands for better performance with higher energy/power densities, improved safety and a longer cycle life. Recently, antimony ( $\mathrm{Sb}$ ) has been extensively researched as a promising candidate due to its high specific capacity through an alloying/dealloying process. In this review article, we will focus on different categories of the emerging $\mathrm{Sb}$ based anode materials with distinct sodium storage mechanisms including $\mathrm{Sb}$, two-dimensional antimonene and antimony chalcogenide $\left(\mathrm{Sb}_{2} \mathrm{~S}_{3}\right.$ and $\left.\mathrm{Sb}_{2} \mathrm{Se}_{3}\right)$. For each part, we emphasize that the novel construction of an advanced nanostructured anode with unique structures could effectively improve sodium storage properties. We also highlight that sodium storage capability can be enhanced through designing advanced nanocomposite materials containing $\mathrm{Sb}$ based materials and other carbonaceous modification or metal supports. Moreover, the recent advances in operando/in-situ investigation of its sodium storage mechanism are also summarized. By providing such a systematic probe, we aim to stress the significance of novel nanostructures and advanced compositing that would contribute to enhanced sodium storage performance, thus making $\mathrm{Sb}$ based materials as promising anodes for next-generation high-performance SIBs.
\end{abstract}

Keywords: antimony; anode; sodium-ion battery; nanostructure; energy storage; in-situ characterization

\section{Introduction}

Currently, lithium-ion batteries (LIBs) have emerged as one of the most important dominant power sources for portable electronic devices, electrical vehicles (EVs) and largescale electrical grids. However, with the great concerns about limited lithium resources available on Earth, the next-generation rechargeable batteries are urgently needed to be based on another non-lithium source [1,2]. Recently, sodium-ion batteries (SIB) have been becoming one potential viable alternative to LIBs, in view of their low cost, environmental benignity, and the natural abundance of sodium resources $[3,4]$. In order to more intuitively reflect the differences between batteries of different systems, the five properties of batteries are presented in the form of a radar diagram in Figure 1a (LMBs and Li-S stand for lithium metal batteries and lithium sulfur batteries, respectively). Research has been, and is being, intensively carried out worldwide to explore reliable electrode materials for highperformance SIBs systems. Compared with the cathodes [5-8], the anodes of SIB exhibit an unstable cycling performance and limited capacities. One of the frustrating drawbacks of anodes is that the well-established anode materials for LIBs, such as graphite and silicon, cannot be operated and used in SIBs. To end this, much effort has been put into developing new anode materials including carbonaceous materials, alloying, conversion/alloying 
materials, and organic compounds. Among various alloying type anode materials for SIBs, antimony $(\mathrm{Sb})$-based materials with high theoretical capacities and appropriate reaction potential are promising anode materials for SIBs $[9,10]$, as evidenced by the increasing number of publications shown in Figure $1 b$.

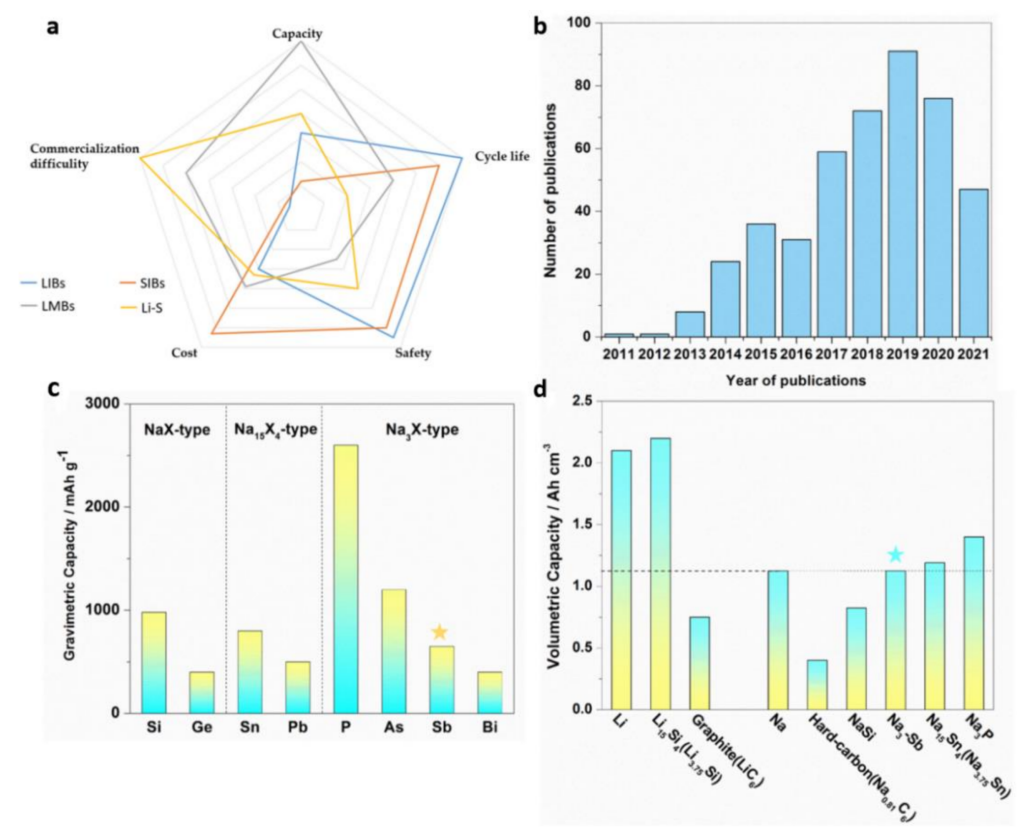

Figure 1. (a) The property of different battery systems. (b) Publications of antimony-based materials as anodes for sodium ion batteries in the last decade. Data from Web of Science. (c) Theoretical gravimetric capacity and (d) volumetric capacity of the mostly studied alloying-based materials for sodium storage.

$\mathrm{Sb}$ is categorized as one of the semimetallic pnictogens and displays a high theoretical capacity of $660 \mathrm{mAh} \mathrm{g}^{-1}$ (corresponding to the formation of $\mathrm{Na}_{3} \mathrm{Sb}$ as the final product of alloying reaction). Among the mostly alloying-based anodes, though the phosphorus anode defines the highest gravimetric energy density (Figure 1c), phosphorus is a nonconductive anode with huge volume expansion and a final flammable $\mathrm{Na}_{3} \mathrm{P}$ discharge product [11], which severely limits its electrochemical performance and widespread practical application. While a bright and optimistic future is expected for $\mathrm{Sb}$ anodes whose volumetric capacity is very competitive towards high energy density SIBs (Figure 1d). In 2012, Monconduit's group first compared the electrochemical performance of $\mathrm{Li}-\mathrm{Sb}$ and $\mathrm{Na}-\mathrm{Sb}$ batteries using pure micrometric $\mathrm{Sb}$ particles as anodes [12]. Surprisingly, in the case of $\mathrm{Na}$, the intermediate phases are mostly amorphous and could not be precisely identified. Besides, they showed that a competition takes place at the end of the discharge of the $\mathrm{Sb} / \mathrm{Na}$ cell between the formation of the hexagonal and the cubic polymorphs of $\mathrm{Na}_{3} \mathrm{Sb}$. This might be partially due to decreased volume expansion upon going from Sb (181.1 $\AA$ ) to hexagonal $\mathrm{Na}_{3} \mathrm{Sb}(237 \AA)$ compared to rock salt $\mathrm{Li}_{3} \mathrm{Sb}(283.8 \AA)$. Afterwards, Baggetto et al. rationalized the amorphization of $\mathrm{Na}_{x} \mathrm{Sb}$ phases by the long ranged strain propagation due to Na-vacancy co-mpared to Li-Sb [13]. In these regards, Sb stands out as one of the most attractive anode materials for SIBs. Meanwhile, other Sb-based chalcogenides, namely $\mathrm{Sb}_{2} \mathrm{~S}_{3}$ and $\mathrm{Sb}_{2} \mathrm{Se}_{3}$, hold similar advantages and a typical conversion/alloying reaction involving $\mathrm{Na}_{\mathrm{x}}-\mathrm{Sb}$ alloying systems [14]; therefore in this review we consider both as Sb-based composite anodes.

However, Sb-based anodes showed capacity fading due to the mechanical failure of the active material caused by huge volume expansion/contraction during the discharge/charge processes. In order to overcome the above problems, various nanostructuring approaches have been applied and have elicited great research interest. The results of experiments and 
theoretical calculations prove that the synergistic effects of different sizes, pores, morphologies and phases, along with a conductive matrix of the rational designed nanostructured electrodes, contribute to the enhanced electrochemical performance. In this review paper, recent progress in developing nanostructured Sb-based composites as high-performance anodes for SIBs are summarized. The preparation of various $\mathrm{Sb}$ nanostructures with different dimensions is briefly introduced, and the effects of the nanostructures on the electrochemical performance are discussed. Moreover, the role of advanced in situ/operando techniques in revealing the electrochemical mechanisms of representative Sb-based anodes is highlighted. At last, the challenges and prospects for Sb-based anodes with nanostructures are also proposed.

\section{Sb-Based Anode}

\subsection{Pure Sb Anode}

Antimony metal is one of the most interesting materials that can alloy electrochemically with $\mathrm{Na}$ ions. For pure $\mathrm{Sb}$ anodes, monodisperse nanoparticulate active materials are ideally suited for studying the effects of size and electrode morphology on the electrochemical performance. A colloidal synthesis of pure $\mathrm{Sb}$ nanocrystals with a mean size tunable in the 10-20 nm range was established (Figure 2a) [15]. Another example is the fabrication of highly ordered pure Sb nanorod arrays with uniform large interval spacing $(190 \mathrm{~nm})$ (Figure 2b) [16]. In return for this electrode design, a superior rate capability for delivering reversible capacities of $557.7 \mathrm{mAh} \mathrm{g}^{-1}$ at $20 \mathrm{~A} \mathrm{~g}^{-1}$ was achieved. Notably, a morphology-controlled chemical dealloying synthesis of a nanoporous pure $\mathrm{Sb}$ anode confirmed that, even without conductive modification, the innovative electrode design would ensure high sodium ion accessibility and strong structural integrity [17].

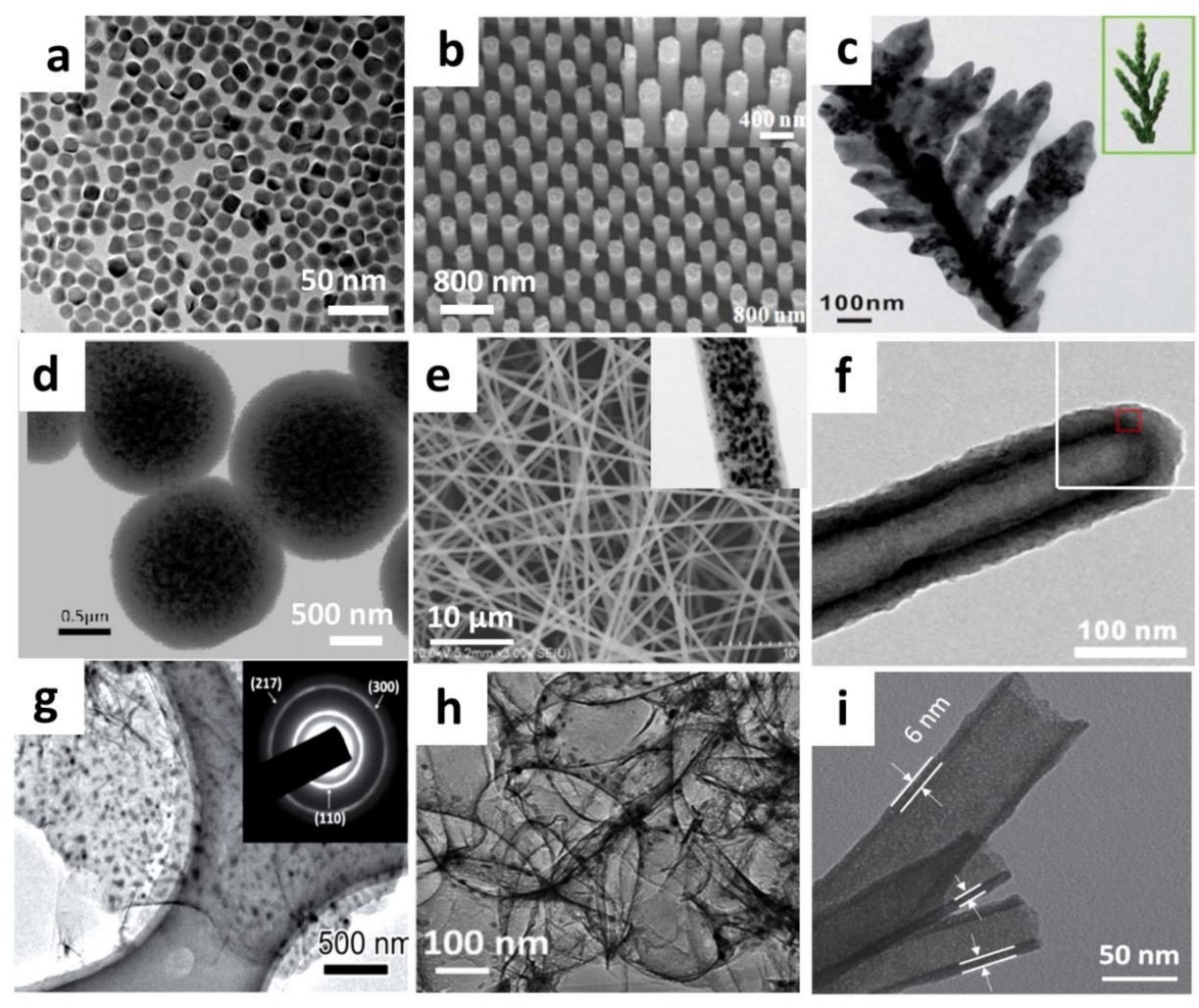

Figure 2. Representative morphologies (SEM or TEM images) of several Sb-based hybrid nanostructured electrodes: (a) monodispersive Sb nanocrystals; (b) ordered Sb nanorods array; (c) cypress-leaf like Sb; (d) Spherical nano-Sb@C composite; (e) Electrospun Sb/C Fibers; (f) Sb@C coaxial nanotubes; (g) $\mathrm{Sb} / \mathrm{rGO}$ paper-like anode; (h) antimony nanoparticles anchored in three-dimensional carbon network; (i) double-walled crystalline Sb@amorphous $\mathrm{TiO}_{2-\mathrm{x}}$ nanotubes. 
Hollow materials have been explored for energy storage applications because of their special structure (high surface area, low density, high loading capacity, and shell permeability), which exhibits excellent properties such as excellent cycle stability and outstanding electronic transport properties [18]. For example, Ji's group fabricated pure $\mathrm{Sb}$ porous hollow microspheres, which were prepared by a galvanic replacement reaction employing Zn microspheres [19] or Ni microspheres [20] as a template. Impressively, the same group also extended the replacement reaction to fabricate cypress leaf-like $\mathrm{Sb}$ for SIBs anode [21] (Figure 2c), which give a superior electrochemical performance with a high reversible capacity of $629 \mathrm{mAh} \mathrm{g}^{-1}$ after 120 cycles, close to its theoretical capacity. More preparation strategies and advances in hollow structures will be discussed in the following parts concerning $\mathrm{Sb} /$ carbonaceous composites anodes.

For better understanding morphological and dimensional changes as well as interior microstructure evolution during reduction/oxidation reactions, Selvaraj et al. conducted transmission X-ray microscopy (TXM) analysis to provide sufficient information [22]. Further work is needed to broaden new routes toward green and convenient methods to synthesize pure $\mathrm{Sb}$ materials with higher chemical and mechanical stability, such as the replacement of toxic organic reagents and/or the development of room-temperature large-scale fabrication of stable alloy electrode materials.

\subsection{Sb/Carbenecous Composite}

Usually, the specific resistivity of untreated pure Sb bulk is 102 103 $\Omega \cdot \mathrm{cm}[23]$, which is still far from satisfactory to ensure fast electron transport when used as electrode materials in a battery. Due to large volume expansion and relative low conductivity of bulk $\mathrm{Sb}$ anodes, Sb-based carbonaceous composites have been proposed to maintain the structural integrity as well as to increase overall conductivity. We categorise various $\mathrm{Sb} /$ carbonaceous composites anodes based on their different morphological dimensional configurations.

Zero-dimensional (0D): $0 \mathrm{D}$ nanostructured $\mathrm{Sb} / \mathrm{C}$ anodes, including quantum dots, nanodots, nanoparticles and hollow spheres and so forth. In the commercial SIBs aspect, 0D nanostructured material holds promise for high tap density electrode fabrication through multiscale assembly [24]. An aerosol spray pyrolysis technique is used to synthesize a spherical nano-Sb@C composite (Figure 2d) [25]. In this regard, nanoscale Sb alloy-based anodes were highlighted by researchers and were intensively investigated concerning its size [26,27], component design [28], composition ratio [29,30], and solid electrolyte interphase (SEI) [31,32]. For example, Ruiz et al. fabricated a macroporous $\mathrm{Sb} /$ magnesium fluoride $\left(\mathrm{MgF}_{2}\right)$ active/inactive composite material as a SIB anode. This new concept of "active/inactive composites" with nanostructure design enables the $\mathrm{Sb} / \mathrm{MgF}_{2}$ anode to deliver a capacity of $551 \mathrm{mAh} \mathrm{g}^{-1}$ after 300 cycles at a C-rate of C/2 [33].

Among them, the design of metallic Sb with hollow structures or a yolk-shell Sb@C structure is a reasonable and significant strategy to improve electrochemical performance for SIBs $[19,34,35]$. Hollow structures refer to materials with well-defined boundaries and interior cavities, which show broad applications in batteries and other energy related devices [18]. Cation exchange reaction based on Kirkendall's effect is an effective way to manipulate the core-shell hollow heterostructures. Benefiting from the unique stable architecture, a hollow core-shell Sb/ZnS@C heterostructure nanosphere anode shows a high reversible capacity, good rate capability and excellent cycling stability [36]. Particularly, Song et al. employed TEM tomography to visualize the architecture and quantify details of the Sb@C yolk-shell structure (Figure 3a) [37]. In this way, the accurate structural information on the core-particle size, the void space and the complex structure can be systemically established (Figure $3 b-e$ ). 


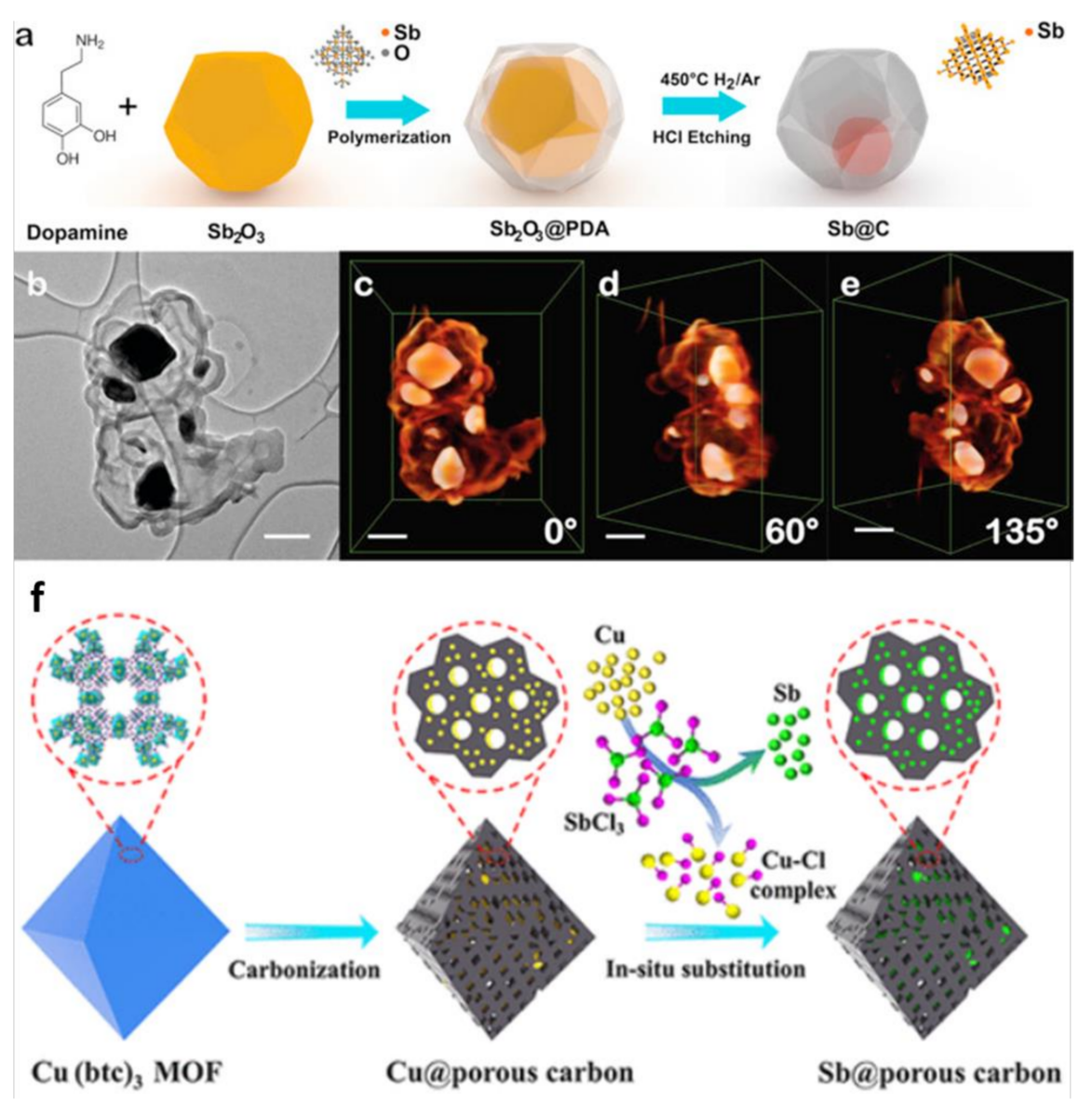

Figure 3. (a) Schematic figure of the synthesis process; (b) TEM image of a typical Sb@C yolk-shell structure; (c-e) Screen shots of the 3D reconstruction of the Sb@C structure (scale bar: $200 \mathrm{~nm}$ ); (f) MOF-derived octahedron carbon framework.

Recently, metal-organic-framework (MOF) derived carbon has shown great capability to realize precise carbon-confined nanostructures with diverse compositions and delicate morphologies [38,39]. For example, $\mathrm{Li}$ et al. reported an ultrafine $\mathrm{Sb}$ embedded in a porous carbon nanocomposite (Sb@PC) synthesized via a facile in situ substitution of the $\mathrm{Cu}$ nanoparticles in an MOF-derived octahedron carbon framework for sodium storage (Figure 3f).

Apart from the aforementioned routines, high-energy ball milling has also been intensively used to realize well-dispersive distribution or formation of intermetallic alloying compounds [40-42]. Besides, the spraying method is an effective method for synthesizing 0D nanostructures, for example, pitaya-like Sb@C microspheres are prepared successfully by facile aerosol spray drying synthesis [43].

One-dimensional(1D): 1D nanomaterials have great capability towards applications in the fields of energy storage since they could ensure electron transport along a long axis and maintain a confinement effect across radial direction [44]. In 2013, Zhu et al. first reported a $\mathrm{Sb} / \mathrm{C}$ electrode with $\sim 30 \mathrm{~nm} \mathrm{Sb}$ nanoparticles uniformly encapsulated in interconnecting 1D $400 \mathrm{~nm}$ carbon fibers by electrospinning method (Figure 2e) [45]. Similar work involving of electrospun $\mathrm{Sb} / \mathrm{C}$ as an SIBs anode was accomplished by Cao et al. almost at the same time [46]. Afterwards, a variety of $1 \mathrm{D} \mathrm{Sb} / \mathrm{C}$ composite anodes have been established including Sb/CNT composite [38], peapod-like Sb@C [47], Sb@C coaxial nanotubes (Figure 2f) [48], N-doped carbon nanonecklaces with encapsulated $\mathrm{Sb}$ [49] and 1D yolk-shell Sb@Ti-O-P nanostructures [50]. Impressively, the full battery of Sb@Ti-O$\mathrm{P} / / \mathrm{Na}_{3} \mathrm{~V}_{2}\left(\mathrm{PO}_{4}\right)_{3}-\mathrm{C}$ presents a high output voltage $(\sim 2.7 \mathrm{~V})$ and a capacity of $392 \mathrm{mAh} \mathrm{g}^{-1}$ after 150 cycles at $1 \mathrm{~A} \mathrm{~g}^{-1}$. 
Galvanic replacement synthesis of the 1D nanostructure is a novel mediated growth strategy to fabricate highly uniform Sb nanotubes [51]. Impressively, a full cell with assynthesized $\mathrm{Sb}$ nanotubes anode and $\mathrm{Na}_{3}\left(\mathrm{VOPO}_{4}\right)_{2} \mathrm{~F}$ cathode, which exhibits a high energy density $\left(252 \mathrm{Wh} \mathrm{kg}^{-1}\right)$ and high output voltage $(2.7 \mathrm{~V})$. With respect to monitoring the structural evolution of 1D Sb@C, Luo et al. also demonstrated a novel synthetic route to fabricate nanorod-in-nanotube Sb@nitrogen-doped carbon composites [52]. The key observation is that an operando high-temperature XRD was conducted to monitor the in-situ structural evolution from $\mathrm{Sb}_{2} \mathrm{~S}_{3}$ sacrifice template to crystalline $\mathrm{Sb}$. Additionally, other $\mathrm{Sb}$ composite anodes based on CNT [53,54] or carbon nanofibers [55] were also proven to demonstrate improved conductivity and enhanced electrochemical performance.

Two-dimensional: In the family of 2D carbonaceous functional materials, carbon nanosheets, graphene or reduced graphene oxide $(\mathrm{rGO})$ sheets and newly emerging $2 \mathrm{D} \mathrm{Mx}-$ ene materials have been widely employed to construct $\mathrm{Sb} / \mathrm{C}$ composites anodes $[26,56-58]$. Graphene incorporation should be one effective strategy for developing advanced electrode materials for SIBs [59-64]. rGO has been improved to interact with $\mathrm{SbO}_{2}$ via C-O-Sb bonds, which effectively improves the conductivity and stability of $\mathrm{Sb} / \mathrm{SbO}_{2} @ \mathrm{rGO}$ composites [65]. In a very recent work, the amorphous feature of $\mathrm{Sb}$ nanoparticles, as well as the synergistic effect between amorphous $\mathrm{Sb}$ and layered nitrogen-doped layered carbon nanosheet, endow the composite with improved electron/ion transport [66].

Notably, graphene modification often introduces heteroatoms doping to further adjust charge transport and adsorption ability. For instance, a promising Sb adsorbent, nitrogen-doped reduced graphene oxide (NGO), was synthesized by a simple hydrothermal method [67]. Benefiting from the structure of graphene, researchers show that the electrophoretic deposition of $\mathrm{Sb}$ nanoparticles embedded in rGO sheets on $\mathrm{Cu}$ foil is a viable technique to fabricate binder-free electrodes [68]. Finally, graphene matrix is an ideal candidate to fabricate a binder-free, flexible electrode for SIBs due to its high mechanical strength and high conductivity. For instance, the $\mathrm{Sb}$ nanoparticles embedded homogenously in the interconnected framework of rGO nanosheets (Figure 2g), which give an excellent rate capacity of up to $30 \mathrm{C}$ and enable SIB full cell to run up 100 charge/discharge cycles [69].

Antimonene, a new-type mono-elemental 2D layered materials (Figure 4a,b), was firstly predicted to exhibit good stability and remarkable physical properties by theoretical investigation [70-72]. Afterwards, mechanical isolation [73], liquid-phase exfoliation [74], aqueous shear exfoliation [75], molecular beam epitaxy [76], van der Waals epitaxy growth [77] and so forth have been demonstrated to obtain high-quality few-layer $\mathrm{Sb}$ exfoliated nanosheets. From the view of first-principles calculations, antimonene exhibits high specific capacity, a small diffusion barrier and low lattice expansion as an anode for SIBs $[78,79]$ and shows relatively small structure deformation upon Li adsorption [80]. Notably, Su et al. proposed a trilayer graphene/antimonene/graphene heterostructure as a potential anode, and their calculation results confirmed that a heterostructure can provide strong binding with $\mathrm{Na}$ and a low-migration barrier for $\mathrm{Na}$ (Figure 4c-h) [81].

Experimentally, antimonene has been successfully synthesized and evaluated in electrochemical energy applications including hydrogen/oxygen evolution reaction (HER/ OER) [75], lithium storage [82] and supercapacitors [83,84]. Concerning the SIBs application, Yang et al. synthesized stable porous antimonene sheets with mesopores, and the as-exfoliated antimonene can deliver a high specific capacity of $569.1 \mathrm{mAh} \mathrm{g}^{-1}$ upon 200 cycles at $100 \mathrm{~mA} \mathrm{~g}^{-1}$ [85]. Impressively, Tian et al. fabricated few-layer 0.38-nminterspacing, 7-nm-thick antimonene anode (Figure 4i-k), which delivered a high capacity of $642 \mathrm{mAh} \mathrm{g}^{-1}$ at $0.1 \mathrm{C}$ (Figure 4l) and a high rate capability of $429 \mathrm{mAh} \mathrm{g}^{-1}$ at $5 \mathrm{C}$ (Figure $4 \mathrm{~m}$ ) [86]. Their results represent the highest capacity and $\mathrm{Sb}$ utilization ratio at the reported time. In a word, the emerging antimonene materials boost promising applications of 2D monoelemental layered materials for advanced energy storage and conversion. 
(a)

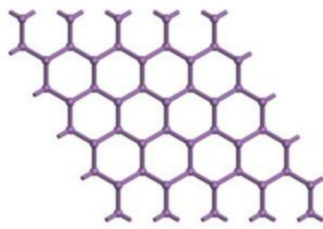
Sb- top view

(c)
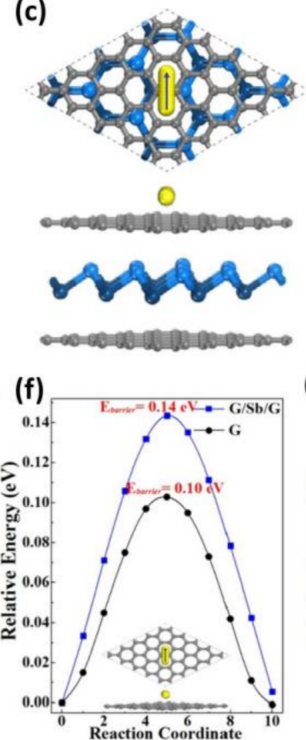

(g) (b)

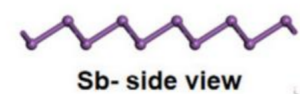

Sb-side view

(i)

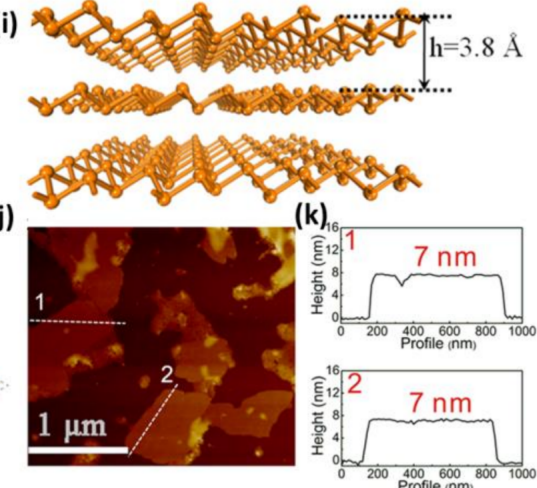

(e)
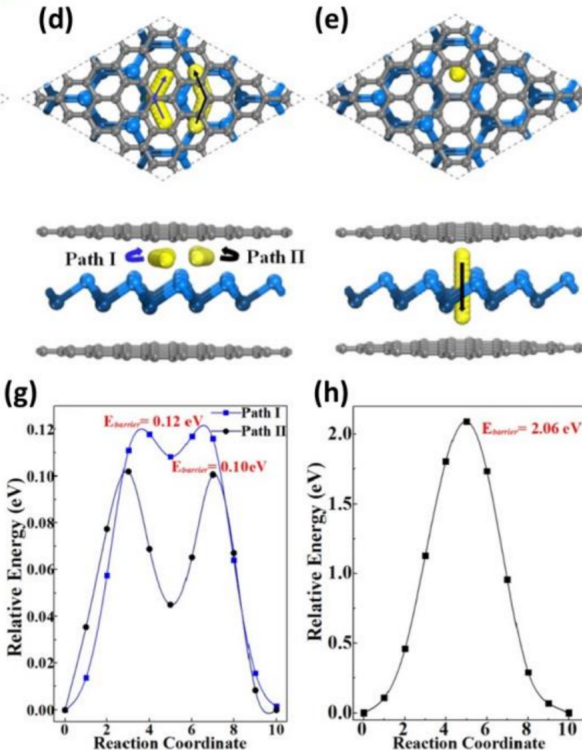

(h)
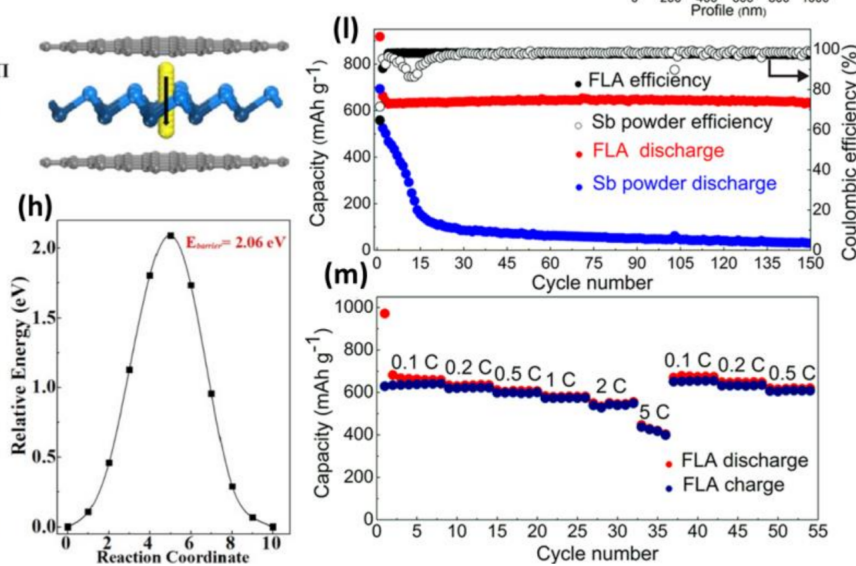

Figure 4. $(\mathbf{a}, \mathbf{b})$ 3D representation of the structures of monolayer antimone. Diffusion pathways and energy barriers of $\mathrm{Na}$ diffusion: (c,f) Outside of the graphene surface, $(\mathbf{d}, \mathbf{g})$ interlayer of the heterostructure, $(\mathbf{e}, \mathbf{h})$ across over the antimonene layer, the grey, blue and yellow spheres represent $\mathrm{C}, \mathrm{Sb}$ and $\mathrm{Na}$ atoms, respectively. (i) Atomic structure illustration, (j) AFM image, (k) profile terraces of few-layer antimonene (1) Long-term cycling performance of the few-layer antimonene and bulk $\mathrm{Sb}$ powder at a rate of $0.5 \mathrm{C}$. (m) Rate capability of few-layer antimonene.

Three-dimensional: Compared to 1D and 2D nanostructures, unique 3D cross-linked networks provide highly conductive frameworks for fast electron/ion transfer electrons and alleviate the volume expansion of Sb nanocrystals during the cycling $[87,88]$. For example, Mai et al. fabricated a novel composite with $\mathrm{Sb}$ nanoparticles anchored in a 3D carbon network (Figure $2 \mathrm{~h}$ ) via a $\mathrm{NaCl}$ template-assisted self-assembly strategy, followed by freeze-drying and one-step in-situ carbonization [89]. They found that a 3D interconnected macroporous carbon framework can not only stabilize the architecture and buffer the volume expansion for $\mathrm{Sb}$ nanoparticles, but also provide high electrical conductivity for the whole electrode. Self-wrapping is another facile and highly efficient way to realize even coating and homogeneous distribution. Through self-wrapping, the ultrasmall $\mathrm{Sb}$ nanoparticles embedded in 3D nitrogen-doped porous carbon matrix anode can deliver a reversible capacity of $138 \mathrm{mAh} \mathrm{g}^{-1}$ even at a very high current density of $32 \mathrm{~A} \mathrm{~g}^{-1}$ [90]. Similar work is a porous self-standing foam electrode built from core-shelled $\mathrm{Sb}_{0} \operatorname{In}_{2} \mathrm{O}_{3}$ nanostructures, which displayed superior high rate capacity $\left(348.9 \mathrm{mAh} \mathrm{g}^{-1}\right.$ even at $\left.20 \mathrm{~A} \mathrm{~g}^{-1}\right)$ [91].

Large volume change and poor conductivity are major concerns for alloy anode design and development. Various efforts have been made to overcome these issues and enhance the electrochemical performance of Sb-based anode materials for SIBs. Among these approaches, the downsizing of Sb particles to 1D and 2D nanoscale level and the control of the morphology of the $\mathrm{Sb}$ particles have been demonstrated as effective ways to enhance cycling stability and rate capability. Another promising strategy is the dispersion of the $\mathrm{Sb}$ particles in carbon matrix that can accommodate volume expansions, which will improve the electronic and ionic conductivities and also the stability of the anodes. In this regard, $\mathrm{Yu}$ et al. employed $\mathrm{Sb}$ into macroporous carbon and fabricated the $\mathrm{Sb}$ encapsulated in $\mathrm{S}$ 
and $\mathrm{N}$ co-doped 3D interconnected macroporous carbon [92]. It should be further noted that $\mathrm{S}$ and $\mathrm{N}$ co-doping introduced more defects and active sites to the carbon framework, thus improving the interfacial adsorption and electrochemical behaviors. Another work on oxygen-bond-enhanced Sb-oxygen-bonding-graphene composite anode also revealed that the in-situ constructed oxygen bonds play a significant role in enhancing Na-storage properties, especially the ultrafast charge/discharge capability [93].

Multidimensional: Multidimensional self-assembled structures combine the fast kinetics of nanomaterials (like 0D nanoparticles, 1D nanowires, 2D nanoflakes) with high tap density of micromaterials. Besides, the tunable preparation of multidimensional microstructures is of great importance for improving the energy density of SIBs [94]. For example, $\mathrm{Li}$ et al. systemically compared the electrochemical performance of 1D, 2D and 3D Sb composites [95]. The as-prepared 2D Sb nanosheets electrodes exhibit high reversible capacity of $620 \mathrm{mAh} \mathrm{g}^{-1}$ and retain $90.2 \%$ of capacity after 100 cycles at $100 \mathrm{~mA} \mathrm{~g}^{-1}$. Another example to show the superiority of multidimensional assembly is the anode composed by $\mathrm{Sb}$ prisms array directly grown on copper substrate via a template-free electrodeposition [58]. The resulting $3 \mathrm{D}$ architecture endows the $\mathrm{Sb}$ array with excellent sodium storage performance. Considering its low cost and scale-up capability, the template-free route may find extensive applications in designing electrode architectures. In summary, despite the huge volume expansion and relatively poor electrical conductivity of $\mathrm{Sb}$ anodes, through various novel nanostructure design approaches and conductive carbonaceous modifications, sodium storage performance can be greatly enhanced to meet high capacity, long life and high rate standards.

\subsection{Sb/Oxide Composite}

Recently, transition oxides have been widely used as functional hosts or modification coatings in various energy storage and conversion devices. In the research of better Sb-based anode, double-walled $\mathrm{Sb} @ \mathrm{TiO}_{2-x}$ nanotubes (Figure 2i) [96], two-dimensional $\mathrm{Sb} @ \mathrm{TiO}_{2-x}$ [97], $\mathrm{Sb} / \mathrm{TiO}_{2}$ particles [98], $\mathrm{Sb@C@} \mathrm{TiO}_{2}$ triple-shell nanoboxes [99] have been reported to confirm the enhancement of titanium oxide to alloy-type anode materials. The $\mathrm{Sb} @ \mathrm{TiO}_{2-x}$ structure takes the advantages of the excellent electrochemical stability of $\mathrm{TiO}_{2-x}$ and the high capacity of $\mathrm{Sb}$ together. Together with its nanoscale size and hollow structure, it shows outstanding electrochemical properties. Impressively, in the full cell of $\mathrm{Sb} @ \mathrm{TiO}_{2-\mathrm{x}} / / \mathrm{Na}_{3} \mathrm{~V}_{2}\left(\mathrm{PO}_{4}\right)_{3}-\mathrm{C}$, the energy density turns out to be $151 \mathrm{Wh} \mathrm{kg}^{-1}$ at $21 \mathrm{~W} \mathrm{~kg}^{-1}$, or $61 \mathrm{Wh} \mathrm{kg}^{-1}$ at $1.83 \mathrm{~kW} \mathrm{~kg}^{-1}$. Similar work on $\mathrm{Sb@C@} \mathrm{TiO}_{2}$ triple-shell nanoboxes further demonstrates the structure's advantage in accommodating volume expansion [99].

In addition to titanium oxides, other types of oxides, such as $\mathrm{Sb}_{2} \mathrm{O}_{3}[100,101]$ and SiOC [102], can also be combined with antimony to make a modification. Because most oxide anode materials have a higher capacity than pure $\mathrm{Sb}$ alloy anodes, thus the introduction of these oxides into hybrid electrodes favor the realization of initial high capacity.

Oxide can be used for modification and its high specific capacity can also make it a potential anode material for sodium ion batteries. Antimony can also be directly used as an electrode material in the form of oxides, such as antimony oxide and antimony oxychloride. Antimony oxide can undergo conversion reactions with sodium ions or alloying reactions with sodium ions. The capacities of these two reactions are $1220 \mathrm{mAh} \mathrm{g}^{-1}$ and $1102 \mathrm{mAh}$ $\mathrm{g}^{-1}$ [103]; the capacity is higher than that of pure Sb alloy anode just like most oxide anode materials. However, some oxides intrinsically possess low electronic conductivity and large volume expansion, leading to poor rate performance and electrochemical stability. Therefore, a more advanced electrode structure design is still highly desired concerning the future development of oxides modification. A lot of optimization has been done on the material, in order to alleviate the volume expansion problem of antimony oxide. After being deposited into a micron-level thin film by electrostatic spray deposition, the $\mathrm{Sb}_{2} \mathrm{O}_{3}$ film can be used as a negative electrode of SIBs with a capacity of $414 \mathrm{mAh} \mathrm{g}^{-1}$ [104]. The one-dimensional $\mathrm{Sb}_{2} \mathrm{O}_{3}$ was also studied, but it does not have as excellent electrochemical 
performance as the $\mathrm{Sb}_{2} \mathrm{O}_{3}$ film, after being synthesized by a solvothermal reaction it only has a capacity of $143 \mathrm{mAh} \mathrm{g}^{-1}$ under $20 \mathrm{~mA} \mathrm{~g}^{-1}$ current density after 30 cycles [105]. On the other hand, in order to improve the electrical conductivity of antimony oxide, the $\mathrm{SbOx}$ particle/reduced graphene oxide composite material is obtained by mechanical ball milling, which can retain a specific capacity of $409 \mathrm{mAh} \mathrm{g}^{-1}$ after 100 cycles [106]. Two-dimensional composite materials of layered antimony oxide and carbon nanosheets were also prepared by the template method. The composite material can still retain a specific capacity of $442 \mathrm{mAh} \mathrm{g}^{-1}$ after 100 cycles [107]. Similarly, the antimony oxide nanosheets grown on carbon cloth can retain a specific capacity of $514 \mathrm{mAh} \mathrm{g}^{-1}$ after 500 cycles [108]. Besides, improving the crystallization and purity of antimony oxide crystals also contributes to the improvement of electrochemical properties. For example, octahedral antimony oxide synthesized by a simple hydrothermal reaction and it shows a high specific capacity of $566 \mathrm{mAh} \mathrm{g}^{-1}$ after 200 cycles [109].

The preparation of nano-scale antimony oxychloride is not complex, it can be obtained by solution-phase methods by adjusting the $\mathrm{pH}$ of the reaction solution and the composition of the reaction solution, we can get antimony oxychloride with different morphologies such as $\mathrm{Sb}_{4} \mathrm{O}_{5} \mathrm{Cl}_{2}$ nanoparticles, $\mathrm{Sb}_{8} \mathrm{O}_{11} \mathrm{Cl}_{2}$ nanoribbons and nanowires [110]. However, if antimony oxychloride was used as the anode of SIBs, better morphology regulation still needs to be explored [111,112]. For example, the electrochemical stability of micron rod antimony chloride oxide is not good enough when used as the anode material of sodium ion batteries, the $\mathrm{Sb}_{8} \mathrm{O}_{11} \mathrm{Cl}_{2}$ micron rod synthesized by the conventional solvothermal method only shows a low current density and a low cycle life. Though its stacked micron-rod structure with a diameter of about $100 \mathrm{~nm}$ cannot withstand the negative effect of volume expansion, $723.4 \mathrm{mAh} \mathrm{g}^{-1}$ specific capacity when first used as the negative electrode of sodium ion batteries can still be obtained, which shows enormous potential of antimony oxychloride [111]. The synthesis of one-dimensional and sheaf-like microcrystal antimony chloride oxide is simple and controllable $[113,114]$, which shows the controllability of the antimony chloride oxide structure and provides the possibility for the optimization of antimony oxychloride. On the other hand, in order to improve cycle life, compounding antimony oxychloride with other functional materials can also bring significant results. For example, the composited material of pure phase $\mathrm{Sb}_{4} \mathrm{O}_{5} \mathrm{Cl}_{2}$ particles and graphene aerogel can have a better electrochemical performance used as anode of SIBs, the specific capacity can be maintained at $400 \mathrm{mAh} \mathrm{g}^{-1}$ after 50 cycles [115].

\subsection{Other Sb Hybrid Composites}

In the above sections, many Sb-based anode materials, including pure $\mathrm{Sb}$ and $\mathrm{Sb}$ / carbonaceous composites, have been reviewed. Additionally, conductive polymer is another promising candidate in the design of a robust nanostructure Sb-based anode $[116,117]$. For example, polyaniline (PANI) coating can further buffer the volume expansion and improve the diffusion rate of sodium ions in the electrode.

Besides, intermetallic multicomponent alloying was utilized as an approach to modifying the morphology and active phases in an effort to improve the cycling stability of $\mathrm{Sb}$ anodes [118], whereby nanostructured $\mathrm{Sb}$ anodes may not play a pivotal role in regulating the electrochemical performance $[28,119]$. Instead, the synergistic effect induced by intermetallic phase, barrier layer or phase transformation would matter [120-122]. Sb-based intermetallics and alloys for SIBs would not be intensively discussed in this review, some important papers or literature reviews can be referred to [123-126]. In order to more directly compare the improvement degree of antimony based materials by different optimization schemes, we compared the structural optimization and functional coating methods of different antimony based materials, and Table 1 shows the comparison results. 
Table 1. Structure preparation and electrochemical properties of different antimony based materials. $\left(\mathrm{mAg}^{-1} \mathrm{represents}^{-}\right.$ current density).

\begin{tabular}{|c|c|c|c|c|}
\hline Materials & Preparation Methods & $\mathrm{mAg}^{-1}$ & Capacity and Cycle Life & Ref. \\
\hline Monodisperse Antimony Nanocrystals & One-pot colloidal synthesis & 330 & $500 \mathrm{mAh} \mathrm{g}^{-1}$ after 50 cycle & [15] \\
\hline Highly ordered $\mathrm{Sb}$ nanorod array & Electrodeposition \& template & 200 & $620 \mathrm{mAh} \mathrm{g}^{-1}$ at the 100 cycle & [16] \\
\hline Nanoporous-antimony Anode & Template method & 100 & $573.8 \mathrm{mAh} \mathrm{g}^{-1}$ after 200 cycles & [17] \\
\hline $\mathrm{Sb}$ porous hollow microspheres & Zinc balls are etched as templates & 100 & $617 \mathrm{mAh} \mathrm{g}^{-1}$ after 100 cycles & [19] \\
\hline Sb Hollow Nanospheres & Nickel spheres are etched as templates & 50 & $622.2 \mathrm{mAh} \mathrm{g}^{-1}$ after 50 cycles & {$[20]$} \\
\hline Cypress leaf-like Sb & Chemical replacement reaction & 100 & $629 \mathrm{mAh} \mathrm{g}^{-1}$ after 120 cycles & {$[21]$} \\
\hline $\mathrm{Sb}$ nanoparticles/matrix & Aerosol spray pyrolysis technique & 100 & $385 \mathrm{mAh} \mathrm{g}^{-1}$ after 500 cycles & [25] \\
\hline Microporous $\mathrm{Sb} / \mathrm{MgF}_{2}$ & Ball milling and heat treatment & 330 & $551 \mathrm{mAh} \mathrm{g}^{-1}$ after 300 cycles & [33] \\
\hline Yolk-shelled Sb@C & Spray drying and heat treatment & 20,000 & $331 \mathrm{mAh} \mathrm{g}^{-1}$ after 10,000 cycles & {$[34]$} \\
\hline Sb/ZnS@C core-shell heterostructure & Hydrothermal and heat treatment & 100 & $554.8 \mathrm{mAh} \mathrm{g}^{-1}$ after 150 cycles & [36] \\
\hline Sb@ porous carbon octahedron & In situ substitution method & 100 & $634.6 \mathrm{mAh} \mathrm{g}^{-1}$ after 200 cycles & {$[38]$} \\
\hline $\mathrm{Sb}_{2} \mathrm{O}_{3} @ \mathrm{Sb}$ nanoparticles & Spray drying and heating treatment & 10,000 & $245.2 \mathrm{mAh} \mathrm{g}^{-1}$ after 10,000 cycles & [43] \\
\hline Electrospun $\mathrm{Sb} / \mathrm{C}$ Fibers & Electrospinning method & 100 & $350 \mathrm{mAh} \mathrm{g}^{-1}$ after 300 cycles & [45] \\
\hline Peapod-likeSb@C & Sintering and chemical replacement & 100 & $559 \mathrm{mAh} \mathrm{g}^{-1}$ after 200 cycles & [47] \\
\hline Sb@C coaxial nanotubes & Thermal-reduction & 100 & $407 \mathrm{mAh} \mathrm{g}^{-1}$ after 240 cycles & [48] \\
\hline N-Doped Carbon Nanonecklaces & Electrostatic spinning & 1000 & $401 \mathrm{mAh} \mathrm{g}^{-1}$ after 6000 cycles & [49] \\
\hline Yolk@Shell Sb@Ti-O-P & Chemical synthesis & 500 & $760 \mathrm{mAh} \mathrm{g}^{-1}$ after 200 cycles & [50] \\
\hline Self-Supported Sb Prisms & Electrochemical deposition & 330 & $531 \mathrm{mAh} \mathrm{g}^{-1}$ after 100 cycles & [58] \\
\hline Porous antimonene & Electrochemical exfoliation & 100 & $569.1 \mathrm{mAh} \mathrm{g}^{-1}$ after 200 cycles & [85] \\
\hline Few-Layer Antimonene & Liquid-phase exfoliation & 330 & $620 \mathrm{mAh} \mathrm{g}^{-1}$ after 150 th cycle & {$[86]$} \\
\hline 3D Porous Sb Foam Anode & Electrodepositing strategy & 300 & $456.5 \mathrm{mAh} \mathrm{g}^{-1}$ after 300 cycles & [91] \\
\hline Double-Walled Sb@ $\mathrm{TiO}_{2-x}$ Nanotubes & Chemical synthesis and calcination & 2640 & $300 \mathrm{mAh} \mathrm{g}^{-1}$ after 1000 cycles & [96] \\
\hline $\mathrm{Sb} @ \mathrm{TiO}_{2-x}$ nanoplates & Salt-template method & 100 & $568 \mathrm{mAh} \mathrm{g}^{-1}$ after 100 cycles & [97] \\
\hline Sb@C@ $@ \mathrm{TiO}_{2}$ Triple-Shell Nanoboxes & Template method & 1000 & $193 \mathrm{mAh} \mathrm{g}^{-1}$ after 4000 cycles & [99] \\
\hline Polyaniline-coated antimony & In situ oxidative polymerization & 330 & $412.4 \mathrm{mAh} \mathrm{g}^{-1}$ after 250 cycles & [116] \\
\hline Sn-Bi-Sb alloys & Sputtering to get alloy film & 200 & $621 \mathrm{mAh} \mathrm{g}^{-1}$ after 100 cycles & [118] \\
\hline
\end{tabular}

\section{Sb-Based Chalcogenide Anode}

Nowadays, metal chalcogenides, namely $\mathrm{Sb}_{2} \mathrm{~S}_{3}$ and $\mathrm{Sb}_{2} \mathrm{Se}_{3}$, have attracted considerable attention owing to their high specific capacity, semiconductivity property and intriguing layered structure for sodium storage [118-129]. Specifically, $\mathrm{Sb}_{2} \mathrm{Se}_{3}$ as one of a V-VI binary semiconductor compound, has received a great deal of attention due to applications of its photovoltaic, thermoelectric and electrochemical properties. For example, Jiang et al. found that the $\mathrm{Sb}_{2} \mathrm{Se}_{3} @ \mathrm{C}$ prepared via the high energy mechanical ball milling of $\mathrm{Sb}$, Se, and carbon black showed a reversible capacity of $650 \mathrm{mAh} \mathrm{g}^{-1}$ at $100 \mathrm{~mA} \mathrm{~g}^{-1}$. A plausible reaction mechanism study has been established through numerous ex-situ or in-situ characterizations [130], and the reaction processes are as follows:

$$
\begin{gathered}
\text { Intercalation reaction: } \mathrm{Sb}_{2} \mathrm{Se}_{3}+\mathrm{xNa}^{+}+\mathrm{xe}^{-1} \rightarrow \mathrm{Na}_{\mathrm{x}} \mathrm{Sb}_{2} \mathrm{Se}_{3} \\
\text { Conversion reaction: } \mathrm{Na}_{x} \mathrm{Sb}_{2} \mathrm{Se}_{3}+(6-\mathrm{x}) \mathrm{Na}^{+}+(6-\mathrm{x}) \mathrm{e}^{-1} \rightarrow 2 \mathrm{Sb}+3 \mathrm{Na}_{2} \mathrm{Se} \\
\text { Alloying reaction: } \mathrm{Sb}+\mathrm{xNa}^{+}+\mathrm{xe}^{-1} \rightarrow \mathrm{Na}_{x} \mathrm{Sb}(\mathrm{x}=1-3) .
\end{gathered}
$$

The improved cycling stability and enhanced electrochemical utilization were attributed to the introduction of carbonaceous modification, which have been established in many $\mathrm{Sb}_{2} \mathrm{Se}_{3}$ based anodes in SIBs [131-133]. Though the theoretical specific capacity is high, the large structural changes limit their cyclability. To address these issues, tremendous efforts have been dedicated to developing novel electrodes, which can be generally classified into two major categories: preparing Sb-based nanostructures and employing carbon matrix. Similar to the construction of above Sb-based anodes, common approaches such as carbonaceous modification (carbon, CNT, graphene) [64,134-141] or conductive polymer buffer coatings [142-144] have been intensively studied, so these works would not be discussed in detail in this section. Advances in nanostructure construction are highlighted by novel approaches, such as ionic liquid-assisted synthesis [145], microwave solution-guided approach [146] and few-layer $2 \mathrm{D} \mathrm{Sb}_{2} \mathrm{~S}_{3}$ prepared by Li intercalation [147]. 
Chalcogenides displays highly anisotropic property, which enables the growth of uniform crystalline 1D nanowires or nanorods. Briefly, for instance, $1 \mathrm{D} \mathrm{Sb}_{2} \mathrm{~S}_{3} @ \mathrm{C}$ nanorods were synthesized via a facile solvothermal reaction [148]. Because the core-shell structure of $\mathrm{Sb}_{2} \mathrm{~S}_{3} @ \mathrm{C}$ and ultrathin carbon layers can effectively alleviate the strain caused by a large volume change and improve the conductivity of electrodes during cycling, the $\mathrm{Sb}_{2} \mathrm{~S}_{3} @ \mathrm{C}$ rods electrode shows a much more remarkable cycle stability and rate capability compared with bare $\mathrm{Sb}_{2} \mathrm{~S}_{3}$ nanorods. A series of $1 \mathrm{D} \mathrm{Sb} \mathrm{S}_{3}$ or $\mathrm{Sb}_{2} \mathrm{Se}_{3}$ based anodes has been reported, such as $\mathrm{Sb}_{2} \mathrm{~S}_{3} / \mathrm{C}$ nanofibers [137], $\mathrm{Sb}_{2} \mathrm{~S}_{3} @ M W C N T$ [149], $\mathrm{Sb}_{2} \mathrm{~S}_{3} / \mathrm{CS}$ nanofibers [150] and $\mathrm{Sb}_{2} \mathrm{Se}_{3} / \mathrm{C}$ nanofibers [151] and $\mathrm{Sb}_{2} \mathrm{~S}_{3} @ \mathrm{~N}-\mathrm{C}$ [152], while in some cases, the amorphous $\mathrm{Sb}_{2} \mathrm{~S}_{3}$ significantly surpass the crystalline counterpart in electrochemical performance [153-155]. It is notable that a $\mathrm{Sb}_{2} \mathrm{~S}_{3}$-graphite $\mathrm{SIB}$ anode has a tap density of $1.3 \mathrm{~g} \mathrm{~cm}^{-3}$, which contributes greatly to the high volumetric capacity of the electrode [156].

Furthermore, hollow nanostructure design has exhibited advantages in increasing the conductivity and buffering the volume change of Sb-based chalcogenides, such as polypyrrole (PPy)-coated $\mathrm{Sb}_{2} \mathrm{Se}_{3}$ microclips [157], multi-shell hollow $\mathrm{Sb}_{2} \mathrm{~S}_{3}$ [158], $\mathrm{Sb}_{2} \mathrm{~S}_{3} @ \mathrm{FeS}_{2}$ hollow nanorods [159], $\mathrm{ZnSe} / \mathrm{Sb}_{2} \mathrm{Se}_{3}$ hollow microspheres [160], and $\mathrm{ZnS}-\mathrm{Sb}_{2} \mathrm{~S}_{3} @ \mathrm{C}$ coredouble shell polyhedron [161]. A typical schematic illustration of self-templating growth of 1D hollow PPy-coated $\mathrm{Sb}_{2} \mathrm{Se}_{3}$ is shown in Figure 5a [157]. Through a template-engaged ion-exchange method, the 1D template, ZnSe(DETA) 0.5 microbelts, gradually reacted with an appropriate amount of $\mathrm{Sb}^{3+}$ ions and converted to $\mathrm{Sb}_{2} \mathrm{Se}_{3}$ microclips. The elemental mapping images clearly confirm the 1D hollow structure with a homogeneous distribution of the $\mathrm{Sb}$, Se, C, and $\mathrm{N}$ elements in the microclip (Figure 5b).
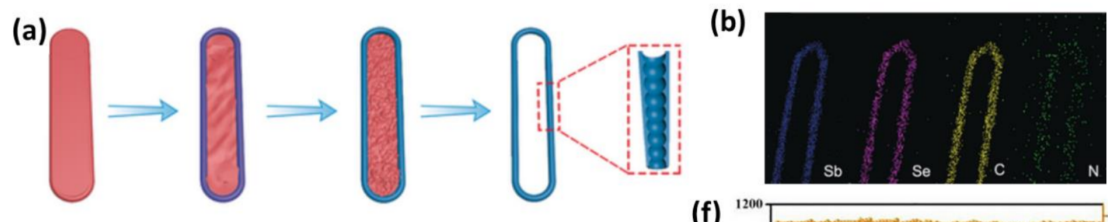

(f)

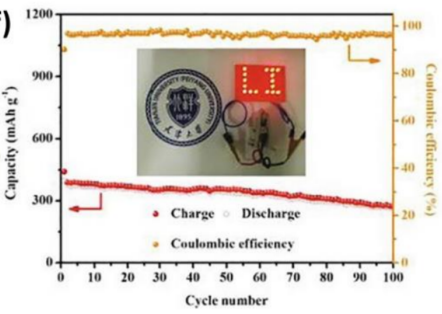

Figure 5. (a) Schematic illustration of the structural evolution process of the ZnSe(DETA)0.5 microbelt to $\mathrm{Sb}_{2} \mathrm{Se}_{3}$ microclip. (b) Elemental mapping images of an individual $\mathrm{Sb}_{2} \mathrm{Se}_{3} @ P P y$ microclip. (c-e) Digital photographs of porous $\mathrm{Sb}_{2} \mathrm{~S}_{3} / \mathrm{TiO}_{2} / \mathrm{C}$ nanofibers with 4 -folded manipulation. (f) Cycle performance of free-standing porous $\mathrm{Sb}_{2} \mathrm{~S}_{3} / \mathrm{TiO}_{2} / \mathrm{C}-\mathrm{LiFePO}_{4}$ full-cell (inset: digital photographs of a full cell that lights 16 LEDs).

Chalcogenides hold promise as a substrate for the construction of high performance, flexible, foldable and twistable electrodes for energy storage [108,162]. For instance, Luo et al. first developed a free-standing membrane based on ultralong $\mathrm{Sb}_{2} \mathrm{Se}_{3}$ nanowires synthesized via a facile hydrothermal method followed by a vacuum filtration process. They found that a free-standing membrane constructed by pure $\mathrm{Sb}_{2} \mathrm{Se}_{3}$ nanowires exhibits good flexibility and integrity [127]. Moreover, a flexible, foldable, and twistable $\mathrm{Sb}_{2} \mathrm{~S}_{3} / \mathrm{TiO}_{2} / \mathrm{C}$ nanofiber membrane was prepared via an electrospinning method [162]. The prepared nanofiber membranes remain intact and crease-free after four-folded manipulation (Figure 5c-e). In lithium-ion full-cells, a high discharge capacity of $261.6 \mathrm{mAh} \mathrm{g}^{-1}$ can be obtained after 100 cycles when cycled at $50 \mathrm{~mA} \mathrm{~g}^{-1}$ (Figure 5f).

From the molecular level, compared to pure $\mathrm{Sb}$ anode, chalcogenides contain an $\mathrm{S}$ or $\mathrm{Se}$ atom, which sometimes act as chemical bonding sites to fabricate high-performance $\mathrm{Sb}_{2} \mathrm{~S}_{3}$ or $\mathrm{Sb}_{2} \mathrm{Se}_{3}$ anode. The strong chemical bonding of nanostructured $\mathrm{Sb}_{2} \mathrm{~S}_{3}$ on heteroatom- 
doped graphene or carbon matrix have been disclosed by electrochemical analysis as well as computational calculations $[38,163]$. It has been found that heteroatoms-doped graphene or carbon usually accounts for the improvement of electronic and ionic conductivity $[164,165]$ or improve the adsorption of $\mathrm{Sb}_{2} \mathrm{~S}_{3}$ on the matrix $[166,167]$. Moreover, density function theory (DFT) calculation confirmed that the sulfur and $\mathrm{Sb}$ doped-carbon substrates increase the adsorption energies, charge transfer, specific capacities and the diffusion properties of $\mathrm{Na}^{+}$ions [168]. A similar effect can be also realized in 2D Mxene-modified chalcogenide anodes for SIB [169]. A recent interesting work revealed that graphene can be also scrolled on $\mathrm{Sb}_{2} \mathrm{~S}_{3}$ nanowires to improve the overall performance [170].

Since Sb-based chalcogenides are typical semiconductor materials, some binary metal sulfides, in view of semiconductor knowledge, have been constructed and studied. Such as $\mathrm{Sb}_{2} \mathrm{~S}_{3} / \mathrm{MoS}_{2}$ heterostructures [171], whereby the built-in electrical field induced by heterojunctions accelerates interfacial charge transportation were realized $[128,172-176]$. One of the explanations of the synergistic effect is that the formation of heterostructures dramatically increases electron transfer in the direction from the n-type semiconductor to the p-type semiconductor due to the built-in electrical field $[177,178]$. Hence, unbalanced charge distribution occurs and more electrons are transferred to heterostructures than in bare $\mathrm{SnS}_{2}$ materials (Figure 6a,b), and this electric field can facilitate the immigration of $\mathrm{Na}^{+}$ ions [179]. Besides, in some work, the combination of $\mathrm{Sb}_{2} \mathrm{~S}_{3}$ and Mxene matrix promotes charge transfer and buffers the volume expansion and inhibits the agglomeration/grain growth of $\mathrm{Sb}_{2} \mathrm{~S}_{3}[180,181]$. Similar phenomena were also confirmed in the bismuth-based $\mathrm{Bi}_{2} \mathrm{~S}_{3}-\mathrm{Bi}_{2} \mathrm{O}_{3}$ (BS-BO) heterostructure anode for SIBs [128]. BS-BO p-n heterojunctions formed at the interface can induce a built-in electric field with a direction from $\mathrm{Bi}_{2} \mathrm{O}_{3}$ $(\mathrm{Eg} \approx 2.8 \mathrm{eV})$ to $\mathrm{Bi}_{2} \mathrm{~S}_{3}(\mathrm{Eg} \approx 1.3 \mathrm{eV})$. It can be anticipated that, during the discharge process, this electric field can facilitate the immigration of $\mathrm{Na}^{+}$ions (Figure $6 \mathrm{c}$ ).
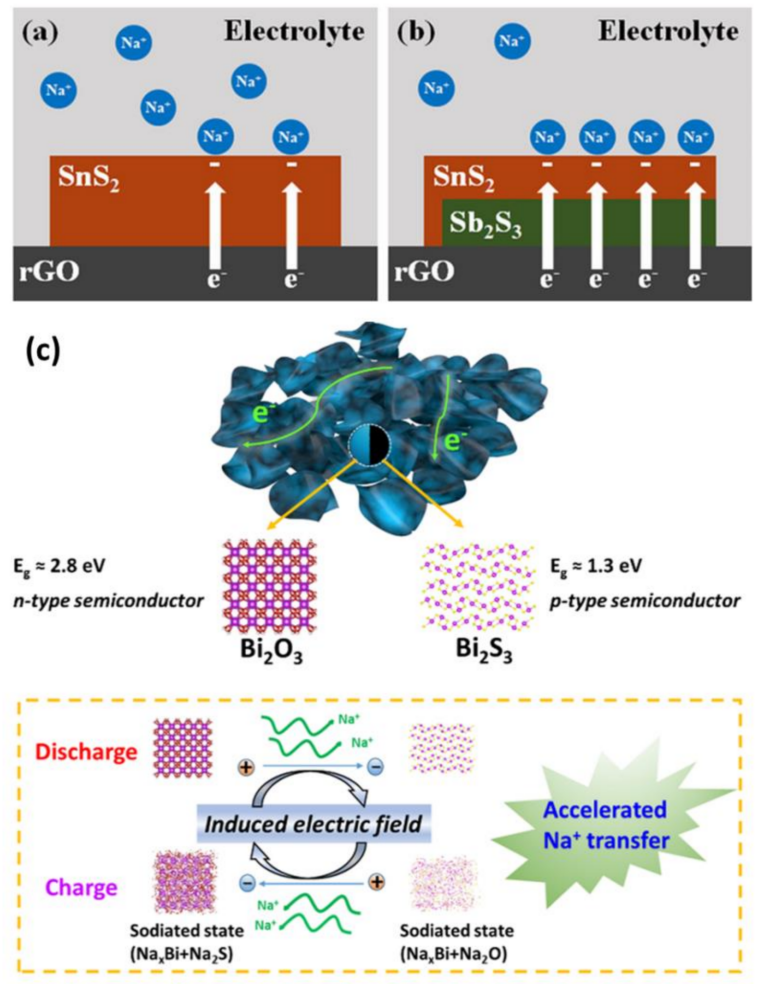

Figure 6. The mechanism of the enhancement of electric conductivity and $\mathrm{Na}^{+}$diffusion kinetics for (a) bare $\mathrm{SnS}_{2}$ and (b) $\mathrm{SnS}_{2} / \mathrm{Sb}_{2} \mathrm{~S}_{3}$ heterostructure. (c) Schematic illustration of the accelerated charge transfer resulted from an induced electric field mechanism in $\mathrm{Bi}_{2} \mathrm{~S}_{3}-\mathrm{Bi}_{2} \mathrm{O}_{3}$ heterostructures. 
Furthermore, Qiao et al. fabricated multi-shell hollow structured $\mathrm{Sb}_{2} \mathrm{~S}_{3}$ anodes exhibiting much higher reversible capacity and gravimetric energy density relative to pristine $\mathrm{Sb}_{2} \mathrm{~S}_{3}$ [158]. More importantly, operando synchrotron X-ray powder diffraction (XRPD) measurements demonstrate that the multi-shell $\mathrm{Sb}_{2} \mathrm{~S}_{3}$ sample reacts efficiently with sodium ions compared to the pristine one, indicating a more complete conversion reaction in the multi-shell sample (Figure 7f,g). Meanwhile, more Sb is detected to generate in the multi-shell sample (Figure 7h,i). Very recently, cryo-TEM has revealed a thin and uniform SEI layer formed on the $\mathrm{a}_{-} \mathrm{Sb}_{2} \mathrm{Se}_{3} / \mathrm{CNT}$ anode [182]. The thickness of the SEI layer is strongly related to the stable electrochemical performance. In a word, in situ characterization techniques have been recognized as powerful tools to track electrochemical reactions of electrode materials in real time, which facilitate the fundamental research and practical applications of high-performance alloying anodes for SIBs and other energy storage systems [183-186].

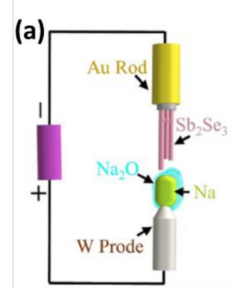

(b)
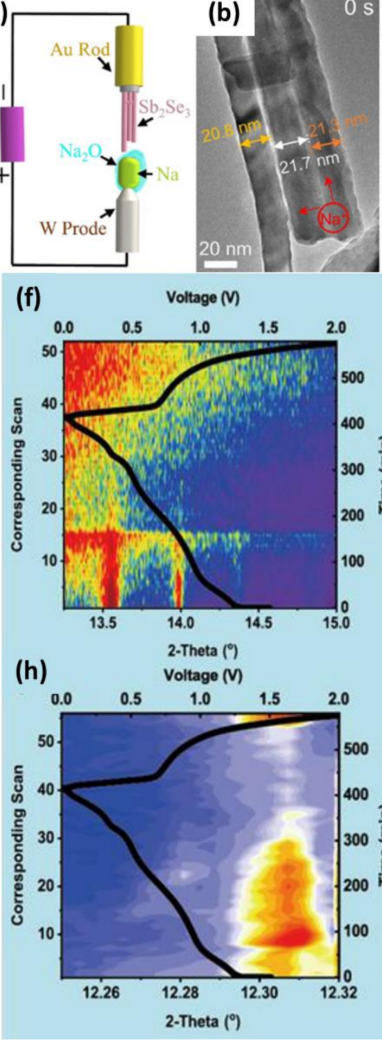
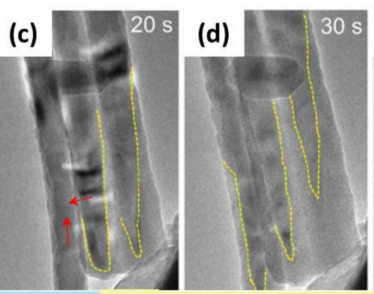

(g)

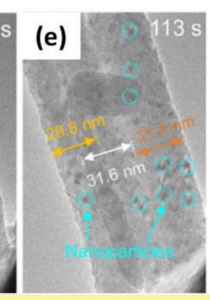

Voltage ( $($ )
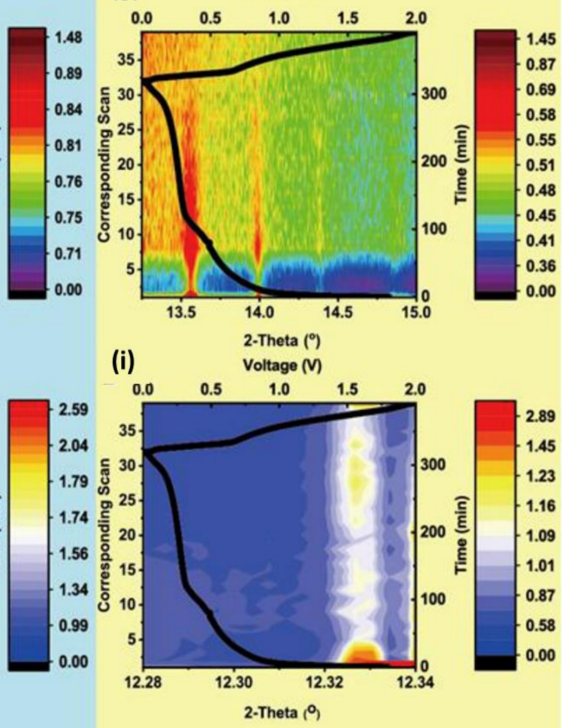

(i)

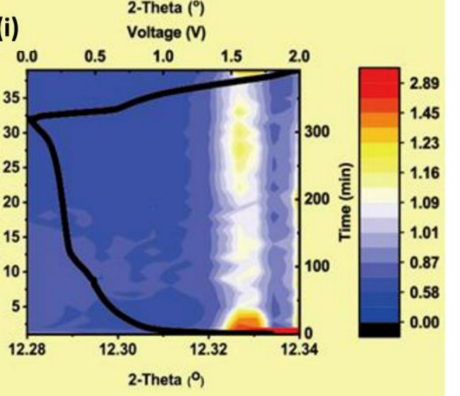

Figure 7. (a) Schematic illustration of the experiment setup for in situ electrochemical sodiation and desodiation. (b-e) Chronological TEM images show morphological evolution of three $\mathrm{Sb}_{2} \mathrm{Se}_{3}$ nanowires during the first sodiation process. Comparison of contour plots of the operando synchrotron X-ray powder diffraction with superimposed voltage profiles shown for selected ranges of (f) multi-shell structured $\mathrm{Sb}_{2} \mathrm{~S}_{3},(\mathrm{~g})$ pristine $\mathrm{Sb}_{2} \mathrm{~S}_{3}$ and their corresponding discharging products $(\mathbf{h}, \mathbf{i})$ whereby $\mathrm{Sb}$ signals were detected.

\section{Conclusions and Outlook}

In conclusion, we summarize different categories of the emerging $\mathrm{Sb}$ based anode materials with distinct sodium storage mechanisms including antimony ( $\mathrm{Sb}$ ) and antimony chalcogenide $\left(\mathrm{Sb}_{2} \mathrm{~S}_{3}\right.$ and $\left.\mathrm{Sb}_{2} \mathrm{Se}_{3}\right)$, and briefly introduce some Sb-based alloys. The major issue associated with using $\mathrm{Sb}$ based anodes is the excessive volume and relatively low conductivity. To mitigate these issues, various nanostructure morphology designs (such as 0D hollow structure, 1D nanostructures and 3D interconnected networks are reviewed), crystal structure designs, conductive matrix modifications, heteroatom-doping 
carbon additive optimizations and so forth, can be used to improve the electrochemical performances of Sb-based alloying anodes. Besides, a new 2D layered monoelemental antimonene and its theoretical/experimental studies on energy storage are highlighted with regards to pure $\mathrm{Sb}$ anodes. Moreover, in regard to Sb-based chalcogenides, beyond their sodium storage performance, their fantastic physicochemical properties/applications such as foldable flexibility, free-standing electrodes, enhanced charge transfer induced by semiconductor heterojunctions, in-situ TEM, operando synchrotron XRD and cryo-TEM studies, are emphasized in this review.

The theoretical capacity of antimony metal as the negative electrode of a sodium ion battery is $660 \mathrm{mAh} \mathrm{g}^{-1}$. Currently, the energy density of lithium-ion batteries can reach up to $300 \mathrm{Wh} \mathrm{kg}^{-1}$. After structural optimization and functional combination, the energy density of a sodium ion battery with an antimony base material as an anode can reach about $200 \mathrm{Wh} \mathrm{kg}^{-1}$. For example, the SIB using Sb array as an anode and $\mathrm{Na}_{0 \cdot 67}\left(\mathrm{Ni}_{0.23} \mathrm{Mg}_{0.1} \mathrm{Mn}_{0 \cdot 67}\right) \mathrm{O}_{2}$ as a cathode, this full cell affords a specific energy of $197 \mathrm{Wh} \mathrm{kg}^{-1}$ at $0.2 \mathrm{C}$ and a specific power of $1280 \mathrm{~W} \mathrm{~kg}^{-1}$ at $5 \mathrm{C}$ [58]. Besides, a full cell assembled with a configuration of $\mathrm{Sb@C@} \mathrm{TiO}_{2} / / \mathrm{Na}_{3}\left(\mathrm{VOPO}_{4}\right)_{2} \mathrm{~F}$ displays a high output voltage of $2.8 \mathrm{~V}$ and a high energy density of $179 \mathrm{Wh} \mathrm{kg}^{-1}$ [99]. A full cell coupled with a $\mathrm{P} 2-\mathrm{Na}_{2 / 3} \mathrm{Ni}_{1 / 3} \mathrm{Mn}_{2 / 3} \mathrm{O}_{2}$ cathode and an $\mathrm{Sb}$ nanorod array anode also shows good cycle performance up to 250 cycles, high rate capability up to $20 \mathrm{~A} \mathrm{~g}^{-1}$, and large energy density up to $130 \mathrm{Wh} \mathrm{kg}^{-1}$ [16]. However, GWh-factories need good safety. Although the antimony based anode optimization method has been widely studied, the safety performance of the whole battery is determined by electrolyte and cathode materials, so the construction of GWh-factories, such as energy storage power stations, is still relatively difficult.

The electrochemical performance of antimony as the anode material of sodium ion batteries has been significantly improved by structural optimization and buffer material composite technology, but the cycle life of the optimized material still cannot meet the needs of practical application. Antimonene, as a two-dimensional material with high entropy, can exist in the environment for a long time and it also has good structural stability. Improving antimonene on the basis of guaranteeing antimonene capacity should become an important link in the process of the practical application of Sb-based electrode materials.

Although the $\mathrm{Sb}$-based anode materials with a nanostructure have realized great progress, there are still some challenges. From academic research to practical commercialization, novel preparation routes with fewer steps and lower costs should be developed. $\mathrm{Sb}$ anodes have superior specific capacity over carbonaceous materials and a competing rate performance over metal oxide. In addition, in situ observation of Sb-based anodes for sodium ion batteries, at full cell or even pouch cell levels, is expected in future research. We hope this review provides insight into the effective design of high-capacity alloying-type anode materials for advanced secondary batteries.

Author Contributions: W.L. prepared the original draft; J.R., W.F., X.C. and Y.Y. edited the figures and tables; W.L., J.R. and W.F. and N.Z. designed the work and edited the manuscript. All authors have read and agreed to the published version of the manuscript.

Funding: This work was supported by the National Natural Science Foundation of China (51904216) and the National Students Innovation and Entrepreneurship Training Program (WUT: S202110497144).

Institutional Review Board Statement: Ethical review and approval were waived for this study, due to the research direction in this field is only for the anode materials of sodium ion batteries.

Informed Consent Statement: Not applicable.

Data Availability Statement: No new data were created or analyzed in this study. Data sharing is not applicable to this article.

Conflicts of Interest: The authors declare no conflict of interest. 


\section{References}

1. Abraham, K.M. How Comparable Are Sodium-Ion Batteries to Lithium-Ion Counterparts? ACS Energy Lett. 2020, 5, $3544-3547$. [CrossRef]

2. Usiskin, R.; Lu, Y.; Popovic, J.; Law, M.; Balaya, P.; Hu, Y.-S.; Maier, J. Fundamentals, status and promise of sodium-based batteries. Nat. Rev. Mater. 2021, 1-16. [CrossRef]

3. Luo, W.; Gaumet, J.-J.; Mai, L.-Q. Antimony-based intermetallic compounds for lithium-ion and sodium-ion batteries: Synthesis, construction and application. Rare Met. 2017, 36, 321-338. [CrossRef]

4. Lao, M.; Zhang, Y.; Luo, W.; Yan, Q.; Sun, W.; Dou, S.X. Alloy-Based Anode Materials toward Advanced Sodium-Ion Batteries. Adv. Mater. 2017, 29, 1700622. [CrossRef] [PubMed]

5. Niu, Y.; Zhang, Y.; Xu, M. A review on pyrophosphate framework cathode materials for sodium-ion batteries. J. Mater. Chem. A 2019, 7, 15006-15025. [CrossRef]

6. Chayambuka, K.; Mulder, G.; Danilov, D.; Notten, P.H.L. Sodium-Ion Battery Materials and Electrochemical Properties Reviewed. Adv. Energy Mater. 2018, 8, 1800079. [CrossRef]

7. Liu, Q.; Hu, Z.; Chen, M.; Zou, C.; Jin, H.; Wang, S.; Chou, S.; Liu, Y.; Dou, S. The Cathode Choice for Commercialization of Sodium-Ion Batteries: Layered Transition Metal Oxides versus Prussian Blue Analogs. Adv. Funct. Mater. 2020, 30, 1909530. [CrossRef]

8. Zhao, C.; Wang, Q.; Yao, Z.; Wang, J.; Sánchez-Lengeling, B.; Ding, F.; Qi, X.; Lu, Y.; Bai, X.; Li, B.; et al. Rational design of layered oxide materials for sodium-ion batteries. Science 2020, 370, 708-711. [CrossRef] [PubMed]

9. Sarkar, S.; Roy, S.; Zhao, Y.; Zhang, J. Recent advances in semimetallic pnictogen (As, Sb, Bi) based anodes for sodium-ion batteries: Structural design, charge storage mechanisms, key challenges and perspectives. Nano Res. 2021, 1-34. [CrossRef]

10. Liang, S.; Cheng, Y.; Zhu, J.; Xia, Y.; Müller-Buschbaum, P. A Chronicle Review of Nonsilicon (Sn, Sb, Ge)-Based Lithium/SodiumIon Battery Alloying Anodes. Small Methods 2020, 4, 2000218. [CrossRef]

11. Zhang, W.; Mao, J.; Li, S.; Chen, Z.; Guo, Z. Phosphorus-Based Alloy Materials for Advanced Potassium-Ion Battery Anode. J. Am. Chem. Soc. 2017, 139, 3316-3319. [CrossRef]

12. Darwiche, A.; Marino, C.; Sougrati, M.T.; Fraisse, B.; Stievano, L.; Monconduit, L. Better Cycling Performances of Bulk Sb in Na-Ion Batteries Compared to Li-Ion Systems: An Unexpected Electrochemical Mechanism. J. Am. Chem. Soc. 2013, 135, 20805-20811. [CrossRef]

13. Baggetto, L.; Ganesh, P.; Sun, C.-N.; Meisner, R.A.; Zawodzinski, T.A.; Veith, G.M. Intrinsic thermodynamic and kinetic properties of Sb electrodes for Li-ion and Na-ion batteries: Experiment and theory. J. Mater. Chem. A 2013, 1, 7985-7994. [CrossRef]

14. Wu, J.; Ihsan-Ul-Haq, M.; Ciucci, F.; Huang, B.; Kim, J.-K. Rationally designed nanostructured metal chalcogenides for advanced sodium-ion batteries. Energy Storage Mater. 2021, 34, 582-628. [CrossRef]

15. He, M.; Kravchyk, K.; Walter, M.; Kovalenko, M. Monodisperse Antimony Nanocrystals for High-Rate Li-ion and Na-ion Battery Anodes: Nano versus Bulk. Nano Lett. 2014, 14, 1255-1262. [CrossRef] [PubMed]

16. Liang, L.; Xu, Y.; Wang, C.; Wen, L.; Fang, Y.; Mi, Y.; Zhou, M.; Zhao, H.; Lei, Y. Large-scale highly ordered Sb nanorod array anodes with high capacity and rate capability for sodium-ion batteries. Energy Environ. Sci. 2015, 8, 2954-2962. [CrossRef]

17. Liu, S.; Feng, J.; Bian, X.; Liu, J.; Xu, H. The morphology-controlled synthesis of a nanoporous-antimony anode for highperformance sodium-ion batteries. Energy Environ. Sci. 2016, 9, 1229-1236. [CrossRef]

18. Zhou, L.; Zhuang, Z.; Zhao, H.; Lin, M.; Zhao, D.; Mai, L. Intricate Hollow Structures: Controlled Synthesis and Applications in Energy Storage and Conversion. Adv. Mater. 2017, 29, 1602914. [CrossRef]

19. Hou, H.; Jing, M.; Yang, Y.; Zhang, Y.; Zhu, Y.; Song, W.; Yang, X.; Ji, X. Sb porous hollow microspheres as advanced anode materials for sodium-ion batteries. J. Mater. Chem. A 2015, 3, 2971-2977. [CrossRef]

20. Hou, H.; Jing, M.; Yang, Y.; Zhu, Y.; Fang, L.; Song, W.; Pan, C.; Yang, X.; Ji, X. Sodium/Lithium Storage Behavior of Antimony Hollow Nanospheres for Rechargeable Batteries. ACS Appl. Mater. Interfaces 2014, 6, 16189-16196. [CrossRef]

21. Hou, H.; Jing, M.; Zhang, Y.; Chen, J.; Huang, Z.; Ji, X. Cypress leaf-like Sb as anode material for high-performance sodium-ion batteries. J. Mater. Chem. A 2015, 3, 17549-17552. [CrossRef]

22. Selvaraj, B.; Wang, C.-C.; Song, Y.-F.; Sheu, H.-S.; Liao, Y.-F.; Wu, N.-L. Remarkable microstructural reversibility of antimony in sodium ion battery anodes. J. Mater. Chem. A 2020, 8, 22620-22625. [CrossRef]

23. Wang, Y.; Brezesinski, T.; Antonietti, M.; Smarsly, B. Ordered Mesoporous Sb-, Nb-, and Ta-Doped SnO 2 Thin Films with Adjustable Doping Levels and High Electrical Conductivity. ACS Nano 2009, 3, 1373-1378. [CrossRef] [PubMed]

24. Tian, J.; Yang, H.; Fu, C.; Sun, M.; Wang, L.; Liu, T. In-situ synthesis of microspherical Sb@C composite anode with high tap density for lithium/sodium-ion batteries. Compos. Commun. 2020, 17, 177-181. [CrossRef]

25. Zhang, N.; Liu, Y.; Lu, Y.; Han, X.; Cheng, F.; Chen, J. Spherical nano-Sb@C composite as a high-rate and ultra-stable anode material for sodium-ion batteries. Nano Res. 2015, 8, 3384-3393. [CrossRef]

26. Wang, G.; Xiong, X.; Lin, Z.; Yang, C.; Lin, Z.; Liu, M. Sb/C composite as a high-performance anode for sodium ion batteries. Electrochim. Acta 2017, 242, 159-164. [CrossRef]

27. Ramireddy, T.; Sharma, N.; Xing, T.; Chen, Y.; Leforestier, J.; Glushenkov, A.M. Size and Composition Effects in Sb-Carbon Nanocomposites for Sodium-Ion Batteries. ACS Appl. Mater. Interfaces 2016, 8, 30152-30164. [CrossRef] [PubMed]

28. Kalisvaart, W.P.; Olsen, B.C.; Luber, E.J.; Buriak, J.M. Sb-Si Alloys and Multilayers for Sodium-Ion Battery Anodes. ACS Appl. Energy Mater. 2019, 2, 2205-2213. [CrossRef] 
29. Liang, S.; Cheng, Y.-J.; Wang, X.; Xu, Z.; Ma, L.; Xu, H.; Ji, Q.; Zuo, X.; Müller-Buschbaum, P.; Xia, Y. Impact of CO $\mathrm{CO}_{2}$ activation on the structure, composition, and performance of $\mathrm{Sb} / \mathrm{C}$ nanohybrid lithium/sodium-ion battery anodes. Nanoscale Adv. 2021, 3, 1942-1953. [CrossRef]

30. Hou, H.; Yang, Y.; Zhu, Y.; Jing, M.; Pan, C.; Fang, L.; Song, W.; Yang, X.; Ji, X. An Electrochemical Study of Sb/Acetylene Black Composite as Anode for Sodium-Ion Batteries. Electrochim. Acta 2014, 146, 328-334. [CrossRef]

31. Bodenes, L.; Darwiche, A.; Monconduit, L.; Martinez, H. The Solid Electrolyte Interphase a key parameter of the high performance of $\mathrm{Sb}$ in sodium-ion batteries: Comparative X-ray Photoelectron Spectroscopy study of Sb/Na-ion and Sb/Li-ion batteries. J. Power Sources 2015, 273, 14-24. [CrossRef]

32. Lu, H.; Wu, L.; Xiao, L.; Ai, X.; Yang, H.; Cao, Y. Investigation of the Effect of Fluoroethylene Carbonate Additive on Electrochemical Performance of Sb-Based Anode for Sodium-Ion Batteries. Electrochim. Acta 2016, 190, 402-408. [CrossRef]

33. Ruiz, O.; Cochrane, M.; Li, M.; Yan, Y.; Ma, K.; Fu, J.; Wang, Z.; Tolbert, S.H.; Shenoy, V.B.; Detsi, E. Enhanced Cycling Stability of Macroporous Bulk Antimony-Based Sodium-Ion Battery Anodes Enabled through Active/Inactive Composites. Adv. Energy Mater. 2018, 8, 1801781. [CrossRef]

34. Chen, B.; Qin, H.; Li, K.; Zhang, B.; Liu, E.; Zhao, N.; Shi, C.; He, C. Yolk-shelled Sb@C nanoconfined nitrogen/sulfur co-doped 3D porous carbon microspheres for sodium-ion battery anode with ultralong high-rate cycling. Nano Energy 2019, 66, 104133. [CrossRef]

35. Yang, C.; Chen, J.; Ji, X.; Pollard, T.P.; Lu, X.; Sun, C.-J.; Hou, S.; Liu, Q.; Liu, C.; Qing, T.; et al. Aqueous Li-ion battery enabled by halogen conversion-intercalation chemistry in graphite. Nat. Cell Biol. 2019, 569, 245-250. [CrossRef]

36. Dong, S.; Li, C.; Li, Z.; Zhang, L.; Yin, L. Mesoporous Hollow Sb/ZnS@C Core-Shell Heterostructures as Anodes for HighPerformance Sodium-Ion Batteries. Small 2018, 14, 1704517. [CrossRef]

37. Song, J.; Yan, P.; Luo, L.; Qi, X.; Rong, X.; Zheng, J.; Xiao, B.; Feng, S.; Wang, C.; Hu, Y.-S.; et al. Yolk-shell structured Sb@C anodes for high energy Na-ion batteries. Nano Energy 2017, 40, 504-511. [CrossRef]

38. Li, Q.; Zhang, W.; Peng, J.; Zhang, W.; Liang, Z.; Wu, J.; Feng, J.; Li, H.; Huang, S. Metal-Organic Framework Derived Ultrafine Sb@Porous Carbon Octahedron via In Situ Substitution for High-Performance Sodium-Ion Batteries. ACS Nano 2021, 15, 15104-15113. [CrossRef]

39. Yu, L.; Zhang, L.; Fu, J.; Yun, J.; Kim, K.H. Hierarchical Tiny-Sb encapsulated in MOFs derived-carbon and TiO $\mathrm{T}_{2}$ hollow nanotubes for enhanced Li/Na-Ion half-and full-cell batteries. Chem. Eng. J. 2021, 417, 129106. [CrossRef]

40. Palanisamy, M.; Pol, V.G.; Evans, S.F.; Jackson, K.; Jafta, C.J.; Bridges, C.A.; Dai, S.; Levine, A.M.; Lee, R.J.; Paranthaman, M.P. Encapsulated $\mathrm{Sb}$ and $\mathrm{Sb}_{2} \mathrm{O}_{3}$ particles in waste-tire derived carbon as stable composite anodes for sodium-ion batteries. Sustain. Energy Fuels 2020, 4, 3613-3622. [CrossRef]

41. Xu, X.; Si, L.; Zhou, X.; Tu, F.; Zhu, X.; Bao, J. Chemical bonding between antimony and ionic liquid-derived nitrogen-doped carbon for sodium-ion battery anode. J. Power Sources 2017, 349, 37-44. [CrossRef]

42. Mun, Y.S.; Yoon, Y.; Hur, J.; Park, M.S.; Bae, J.; Kim, J.H.; Yoon, Y.S.; Yoo, I.S.; Lee, S.G.; Kim, I.T. Copper-antimony-red phosphorus composites as promising anode materials for sodium-ion batteries. J. Power Sources 2017, 362, 115-122. [CrossRef]

43. Xu, A.; Huang, C.; Li, G.; Zou, K.; Sun, H.; Fu, L.; Ju, J.; Song, Y.; Wu, S.; Xu, Z.; et al. Sb $\mathrm{O}_{2} \mathrm{O}_{3} @ S b$ nanoparticles impregnated in N-doped carbon microcages for ultralong life and high-rate sodium ion batteries. J. Mater. Chem. A 2021, 9, 12169-12178. [CrossRef]

44. Zhou, G.; Xu, L.; Hu, G.; Mai, L.; Cui, Y. Nanowires for Electrochemical Energy Storage. Chem. Rev. 2019, 119, 11042-11109. [CrossRef] [PubMed]

45. Zhu, Y.; Han, X.; Xu, Y.; Liu, Y.; Zheng, S.; Xu, K.; Hu, L.; Wang, C. Electrospun Sb/C Fibers for a Stable and Fast Sodium-Ion Battery Anode. ACS Nano 2013, 7, 6378-6386. [CrossRef]

46. Wu, L.; Hu, X.; Qian, J.; Pei, F.; Wu, F.; Mao, R.; Ai, X.; Yang, H.; Cao, Y. Sb-C nanofibers with long cycle life as an anode material for high-performance sodium-ion batteries. Energy Environ. Sci. 2014, 7, 323-328. [CrossRef]

47. Yang, K.; Tang, J.; Liu, Y.; Kong, M.; Zhou, B.; Shang, Y.; Zhang, W.-H. Controllable Synthesis of Peapod-like Sb@C and Corn-like C@Sb Nanotubes for Sodium Storage. ACS Nano 2020, 14, 5728-5737. [CrossRef]

48. Liu, Z.; Yu, X.-Y.; Lou, X.W.; Paik, U. Sb@C coaxial nanotubes as a superior long-life and high-rate anode for sodium ion batteries. Energy Environ. Sci. 2016, 9, 2314-2318. [CrossRef]

49. Jing, W.T.; Zhang, Y.; Gu, Y.; Zhu, Y.F.; Yang, C.C.; Jiang, Q. N-Doped Carbon Nanonecklaces with Encapsulated Sb as a Sodium-Ion Battery Anode. Matter 2019, 1, 720-733. [CrossRef]

50. Wang, N.; Bai, Z.; Qian, Y.; Yang, J. One-Dimensional Yolk-Shell Sb@Ti-O-P Nanostructures as a High-Capacity and High-Rate Anode Material for Sodium Ion Batteries. ACS Appl. Mater. Interfaces 2017, 9, 447-454. [CrossRef]

51. Liu, Y.; Zhou, B.; Liu, S.; Ma, Q.; Zhang, W.-H. Galvanic Replacement Synthesis of Highly Uniform Sb Nanotubes: Reaction Mechanism and Enhanced Sodium Storage Performance. ACS Nano 2019, 13, 5885-5892. [CrossRef] [PubMed]

52. Luo, W.; Li, F.; Gaumet, J.-J.; Magri, P.; Diliberto, S.; Zhou, L.; Mai, L. Bottom-Up Confined Synthesis of Nanorod-in-Nanotube Structured Sb@N-C for Durable Lithium and Sodium Storage. Adv. Energy Mater. 2018, 8, 1703237. [CrossRef]

53. Zhou, X.; Dai, Z.; Bao, J.; Guo, Y.-G. Wet milled synthesis of an Sb/MWCNT nanocomposite for improved sodium storage. J. Mater. Chem. A 2013, 1, 13727-13731. [CrossRef]

54. Li, X.; Qu, J.; Hu, Z.; Xie, H.; Yin, H. Electrochemically converting $\mathrm{Sb}_{2} \mathrm{~S}_{3} / \mathrm{CNTs}$ to Sb/CNTs composite anodes for sodium-ion batteries. Int. J. Hydrogen Energy 2021, 46, 17071-17083. [CrossRef] 
55. Liu, H.; Wang, Z.; Wu, Z.; Zhang, S.; Ge, S.; Guo, P.; Hua, M.; Lu, X.; Wang, S.; Zhang, J. Direct tuning of meso-/micro-porous structure of carbon nanofibers confining $\mathrm{Sb}$ nanocrystals for advanced sodium and potassium storage. J. Alloy. Compd. 2020, 833, 155127. [CrossRef]

56. Zhang, D.; Wang, C.; Xue, H.; Wang, S.; Shen, Y.; Wang, Z.; Chang, L.; Liu, W.; Cheng, Y.; Wang, L. High-rate lithium/sodium storage capacities of nitrogen-enriched porous antimony composite prepared from organic-inorganic ligands. Appl. Surf. Sci. 2021, 563, 150297. [CrossRef]

57. Xie, T.; Zhang, Z.; Lin, X.; Shen, Y.; Li, Q. The Sb/SbPO ${ }_{4}^{@ 3 D-G ~ c o m p o s i t e ~ a s ~ a ~ p r o m i s i n g ~ a n o d e ~ m a t e r i a l ~ f o r ~ s o d i u m-i o n ~ b a t t e r i e s . ~}$ Inorg. Chem. Front. 2020, 7, 3448-3455. [CrossRef]

58. Li, X.; Sun, M.; Ni, J.; Li, L. Template-Free Construction of Self-Supported Sb Prisms with Stable Sodium Storage. Adv. Energy Mater. 2019, 9, 1901096. [CrossRef]

59. Wang, G.-Z.; Feng, J.-M.; Dong, L.; Li, X.-F.; Li, D.-J. Porous graphene anchored with $\mathrm{Sb} / \mathrm{SbO}_{\mathrm{x}}$ as sodium-ion battery anode with enhanced reversible capacity and cycle performance. J. Alloys Compd. 2017, 693, 141-149. [CrossRef]

60. Gong, S.; Lee, J.; Kim, H. Development of electrode architecture using Sb-rGO composite and CMC binder for high-performance sodium-ion battery anodes. J. Korean Ceram. Soc. 2020, 57, 91-97. [CrossRef]

61. Li, X.; Qu, J.; Xie, H.; Song, Q.; Fu, G.; Yin, H. An electro-deoxidation approach to co-converting antimony oxide/graphene oxide to antimony/graphene composite for sodium-ion battery anode. Electrochim. Acta 2020, 332, 135501. [CrossRef]

62. Liu, X.; Gao, M.; Yang, H.; Zhong, X.; Yu, Y. 2D sandwich-like nanosheets of ultrafine Sb nanoparticles anchored to graphene for high-efficiency sodium storage. Nano Res. 2017, 10, 4360-4367. [CrossRef]

63. Hwang, C.; Choi, S.; Jung, G.Y.; Yang, J.; Kwak, S.K.; Park, S.; Song, H.-K. Graphene-wrapped Porous Sb Anodes for Sodium-Ion Batteries by Mechanochemical Compositing and Metallomechanical Reduction of $\mathrm{Sb}_{2} \mathrm{O}$. Ele. Acta 2017, 252, 25-32. [CrossRef]

64. Wu, F.; Guo, X.; Li, M.; Xu, H. One-step hydrothermal synthesis of $\mathrm{Sb}_{2} \mathrm{~S}_{3} /$ reduced graphene oxide nanocomposites for highperformance sodium ion batteries anode materials. Ceram. Int. 2017, 43, 6019-6023. [CrossRef]

65. Liu, J.-H.; Li, Y.-F.; Shi, Y.-H.; Guo, J.-Z.; Yang, J.; Wu, X.-L.; Zhang, J.-P.; Hu, W.; Sun, H.-Z. Boron-doped Sb/SbO $@ @$ rGO composites with tunable components and enlarged lattice spacing for high-rate sodium-ion batteries. J. Phys. D Appl. Phys. 2021, 54, 315505. [CrossRef]

66. Yang, J.; Li, J.; Wang, T.; Notten, P.H.; Ma, H.; Liu, Z.; Wang, C.; Wang, G. Novel hybrid of amorphous Sb/N-doped layered carbon for high-performance sodium-ion batteries. Chem. Eng. J. 2021, 407, 127169. [CrossRef]

67. Guo, L.; Vafakhah, S.; Ding, M.; Pam, M.E.; Wang, Y.; Shang, Y.; Huang, S.; Gu, C.; Von Lim, Y.; Yang, H.Y. Direct antimony recovery from wastewater as anode materials for sodium-ion batteries. Mater. Today Energy 2020, 16, 100403. [CrossRef]

68. Ld, A.; Dd, B.; Ps, A. Binder-free electrophoretic deposition of $\mathrm{Sb} / \mathrm{rGO}$ on $\mathrm{Cu}$ foil for superior electrochemical performance in Li-ion and Na-ion batteries. Electrochim. Acta 2020, 358, 136948.

69. Zhang, W.; Liu, Y.; Chen, C.; Li, Z.; Huang, Y.; Hu, X. Flexible and binder-free electrodes of Sb/rGO and $\mathrm{Na}_{3} \mathrm{~V}_{2}\left(\mathrm{PO}_{4}\right)_{3} / \mathrm{rGO}$ nanocomposites for sodium-ion batteries. Small 2015, 11, 3822-3829. [CrossRef] [PubMed]

70. Ares, P.; Palacios, J.J.; Abellán, G.; Gómez-Herrero, J.; Zamora, F. Recent Progress on Antimonene: A New Bidimensional Material. Adv. Mater. 2018, 30, 2. [CrossRef]

71. Wang, G.; Pandey, R.; Karna, S.P. Atomically Thin Group V Elemental Films: Theoretical Investigations of Antimonene Allotropes. ACS Appl. Mater. Interfaces 2015, 7, 11490-11496. [CrossRef]

72. Zhang, S.; Yan, Z.; Li, Y.; Chen, Z.; Zeng, H. Atomically Thin Arsenene and Antimonene: Semimetal-Semiconductor and Indirect-Direct Band-Gap Transitions. Angew. Chem. Int. Ed. 2015, 127, 3155-3158. [CrossRef]

73. Ares, P.; Aguilar-Galindo, F.; Rodríguez-San-Miguel, D.; Aldave, D.A.; Díaz-Tendero, S.; Alcamí, M.; Martín, F.; Gómez-Herrero, J.; Zamora, F. Mechanical Isolation of Highly Stable Antimonene under Ambient Conditions. Adv. Mater. 2016, 28, $6332-6336$. [CrossRef]

74. Gibaja, C.; Rodriguez-San-Miguel, D.; Ares, P.; Gómez-Herrero, J.; Zamora, F. Few-Layer Antimonene by Liquid-Phase Exfoliation. Angew. Chem. Int. Ed. 2016, 128, 14557-14561. [CrossRef]

75. GusmãO, R.; Sofer, Z.; BoušA, D.; Pumera, M. Pnictogen (As, Sb, Bi) Nanosheets for Electrochemical Applications Are Produced by Shear Exfoliation Using Kitchen Blenders. Angew. Chem. Int. Ed. 2017, 129, 14609-14614. [CrossRef]

76. Chen, H.-A.; Sun, H.; Wu, C.-R.; Wang, Y.-X.; Lee, P.-H.; Pao, C.-W.; Lin, S.-Y. Single-Crystal Antimonene Films Prepared by Molecular Beam Epitaxy: Selective Growth and Contact Resistance Reduction of the 2D Material Heterostructure. ACS Appl. Mater. Interfaces 2018, 10, 15058-15064. [CrossRef] [PubMed]

77. Ji, J.; Song, X.; Liu, J.; Yan, Z.; Huo, C.; Zhang, S.; Su, M.; Liao, L.; Wang, W.; Ni, Z.; et al. Two-dimensional antimonene single crystals grown by van der Waals epitaxy. Nat. Commun. 2016, 7, 13352. [CrossRef] [PubMed]

78. Upadhyay, S.; Srivastava, P. Modelling of antimonene as an anode material in sodium-ion battery: A first-principles study. Mater. Chem. Phys. 2020, 241, 122381. [CrossRef]

79. Sengupta, A.; Frauenheim, T. Lithium and sodium adsorption properties of monolayer antimonene. Mater. Today Energy 2017, 5, 347-354. [CrossRef]

80. Su, J.; Duan, T.; Li, W.; Xiao, B.; Zhou, G.; Pei, Y.; Wang, X. A first-principles study of 2D antimonene electrodes for Li ion storage. Appl. Surf. Sci. 2018, 462, 270-275. [CrossRef]

81. Su, J.; Li, W.; Duan, T.; Xiao, B.; Wang, X.; Pei, Y.; Zeng, X.C. Graphene/antimonene/graphene heterostructure: A potential anode for sodium-ion batteries. Carbon 2019, 153, 767-775. [CrossRef] 
82. Gao, Y.; Tian, W.; Huo, C.; Zhang, K.; Guo, S.; Zhang, S.; Song, X.; Jiang, L.; Huo, K.; Zeng, H. Tailoring natural layered $\beta$-phase antimony into few layer antimonene for Li storage with high rate capabilities. J. Mater. Chem. A 2019, 7, 3238-3243. [CrossRef]

83. Martínez-Periñán, E.; Down, M.P.; Gibaja, C.; Lorenzo, E.; Zamora, F.; Banks, C.E. Antimonene: A Novel 2D Nanomaterial for Supercapacitor Applications. Adv. Energy Mater. 2018, 8, 1702606. [CrossRef]

84. Yu, J.; Zhou, J.; Yao, P.; Xie, H.; Zhang, M.; Ji, M.; Liu, H.; Liu, Q.; Zhu, C.; Xu, J. Antimonene Engineered Highly Deformable Freestanding Electrode with Extraordinarily Improved Energy Storage Performance. Adv. Energy Mater. $2019,9,1902462$. [CrossRef]

85. Yang, Y.; Leng, S.; Shi, W. Electrochemical exfoliation of porous antimonene as anode materials for sodium-ion batteries. Electrochem. Commun. 2021, 126, 107025. [CrossRef]

86. Tian, W.; Zhang, S.; Huo, C.; Zhu, D.; Li, Q.; Wang, L.; Ren, X.; Xie, L.; Guo, S.; Chu, P.K.; et al. Few-Layer Antimonene: Anisotropic Expansion and Reversible Crystalline-Phase Evolution Enable Large-Capacity and Long-Life Na-Ion Batteries. ACS Nano 2018, 12, 1887-1893. [CrossRef] [PubMed]

87. Cui, C.; Xu, J.; Zhang, Y.; Wei, Z.; Mao, M.; Lian, X.; Wang, S.; Yang, C.; Fan, X.; Ma, J.; et al. Antimony Nanorod Encapsulated in Cross-Linked Carbon for High-Performance Sodium Ion Battery Anodes. Nano Lett. 2019, 19, 538-544. [CrossRef] [PubMed]

88. Chen, B.; Yang, L.; Bai, X.; Wu, Q.; Liang, M.; Wang, Y.; Zhao, N.; Shi, C.; Zhou, B.; He, C. Heterostructure Engineering of Core-Shelled Sb@Sb $\mathrm{O}_{3}$ Encapsulated in 3D N-Doped Carbon Hollow-Spheres for Superior Sodium/Potassium Storage. Small 2021, 17, 2006824. [CrossRef] [PubMed]

89. Luo, W.; Zhang, P.; Wang, X.; Li, Q.; Dong, Y.; Hua, J.; Zhou, L.; Mai, L. Antimony nanoparticles anchored in three-dimensional carbon network as promising sodium-ion battery anode. J. Power Sources 2016, 304, 340-345. [CrossRef]

90. Duan, J.; Zhang, W.; Wu, C.; Fan, Q.; Zhang, W.; Hu, X.; Huang, Y. Self-wrapped Sb/C nanocomposite as anode material for High-performance sodium-ion batteries. Nano Energy 2015, 16, 479-487. [CrossRef]

91. Fan, X.-Y.; Jiang, Z.; Huang, L.; Wang, X.; Han, J.; Sun, R.; Gou, L.; Li, D.-L.; Ding, Y.-L. 3D Porous Self-Standing Sb Foam Anode with a Conformal Indium Layer for Enhanced Sodium Storage. ACS Appl. Mater. Interfaces 2020, 12, 20344-20353. [CrossRef] [PubMed]

92. Yang, C.; Li, W.; Yang, Z.; Gu, L.; Yu, Y. Nanoconfined antimony in sulfur and nitrogen co-doped three-dimensionally (3D) interconnected macroporous carbon for high-performance sodium-ion batteries. Nano Energy 2015, 18, 12-19. [CrossRef]

93. Wan, F.; Guo, J.-Z.; Zhang, X.-H.; Zhang, J.-P.; Sun, H.-Z.; Yan, Q.; Han, D.-X.; Niu, L.; Wu, X.-L. In Situ Binding Sb Nanospheres on Graphene via Oxygen Bonds as Superior Anode for Ultrafast Sodium-Ion Batteries. ACS Appl. Mater. Interfaces 2016, 8 , 7790-7799. [CrossRef] [PubMed]

94. Tan, S.; Jiang, Y.; Wei, Q.; Huang, Q.; Dai, Y.; Xiong, F.; Li, Q.; An, Q.; Xu, X.; Zhu, Z.; et al. Multidimensional Synergistic Nanoarchitecture Exhibiting Highly Stable and Ultrafast Sodium-Ion Storage. Adv. Mater. 2018, 30, e1707122. [CrossRef]

95. Li, H.; Wang, K.; Zhou, M.; Li, W.; Tao, H.; Wang, R.; Cheng, S.; Jiang, K. Facile Tailoring of Multidimensional Nanostructured Sb for Sodium Storage Applications. ACS Nano 2019, 13, 9533-9540. [CrossRef]

96. Wang, N.; Bai, Z.; Qian, Y.; Yang, J. Double-Walled Sb@TiO2x Nanotubes as a Superior High-Rate and Ultralong-Lifespan Anode Material for Na-Ion and Li-Ion Batteries. Adv. Mater. 2016, 28, 4126-4133. [CrossRef]

97. Li, P.; Guo, X.; Wang, S.; Zang, R.; Li, X.; Man, Z.; Li, P.; Liu, S.; Wu, Y.; Wang, G. Two-dimensional Sb@TiO $2-x$ nanoplates as a high-performance anode material for sodium-ion batteries. J. Mater. Chem. A 2019, 7, 2553-2559. [CrossRef]

98. Zhou, L.; Cheng, Y.; Sun, Q.; Sun, L.; Wang, C.; Wang, X.; Yin, D.; Wang, L.; Ming, J. High alkaline ion storage capacity of hollow interwoven structured $\mathrm{Sb} / \mathrm{TiO}_{2}$ particles: The galvanic replacement formation mechanism and volumetric buffer effect. Chem. Commun. 2018, 54, 4049-4052. [CrossRef]

99. Kong, M.; Liu, Y.; Zhou, B.; Yang, K.; Zhang, W.H. Rational Design of Sb@C@TiO 2 Triple-Shell Nanoboxes for High-Performance Sodium-Ion Batteries. Small 2020, 16, e2001976. [CrossRef]

100. Ye, J.; Xia, G.; Zheng, Z.; Hu, C. Facile controlled synthesis of coral-like nanostructured $\mathrm{Sb}_{2} \mathrm{O}_{3} @ S b$ anode materials for high performance sodium-ion batteries. Int. J. Hydrogen Energy 2020, 45, 9969-9978. [CrossRef]

101. Pan, J.; Wang, N.; Zhou, Y.; Yang, X.; Zhou, W.; Qian, Y.; Yang, J. Simple synthesis of a porous Sb/Sb ${ }_{2} \mathrm{O}_{3}$ nanocomposite for a high-capacity anode material in Na-ion batteries. Nano Res. 2017, 10, 1794-1803. [CrossRef]

102. Lee, Y.; Lee, K.Y.; Choi, W. One-Pot Synthesis of Antimony-Embedded Silicon Oxycarbide Materials for High-Performance Sodium-Ion Batteries. Adv. Funct. Mater. 2017, 27, 1702607. [CrossRef]

103. Li, N.; Liao, S.; Sun, Y.; Song, H.W.; Wang, C.X. Uniformly dispersed self-assembled growth of Sb $\mathrm{O}_{3} / \mathrm{Sb}_{\mathrm{O}} \mathrm{graphene}$ nanocomposites on a 3D carbon sheet network for high Na-storage capacity and excellent stability. J. Mater. Chem. A 2015, 3, 5820-5828. [CrossRef]

104. Hu, M.; Jiang, Y.; Sun, W.; Wang, H.; Jin, C.; Yan, M. Reversible Conversion-Alloying of $\mathrm{Sb}_{2} \mathrm{O}_{3}$ as a High-Capacity, High-Rate, and Durable Anode for Sodium Ion Batteries. ACS Appl. Mater. Interfaces 2014, 6, 19449-19455. [CrossRef] [PubMed]

105. Li, K.; Liu, H.; Wang, G. $\mathrm{Sb}_{2} \mathrm{O}_{3}$ Nanowires as Anode Material for Sodium-Ion Battery. Arab. J. Sci. Eng. 2014, 39, 6589-6593. [CrossRef]

106. Zhou, X.; Liu, X.; Xu, Y.; Liu, Y.; Dai, Z.; Bao, J. An SbO $/$ /Reduced Graphene Oxide Composite as a High-Rate Anode Material for Sodium-Ion Batteries. J. Phys. Chem. C 2014, 118, 23527-23534. [CrossRef]

107. Li, W.; Wang, K.; Cheng, S.; Jiang, K. A two-dimensional hybrid of $\mathrm{SbO}_{\mathrm{x}}$ nanoplates encapsulated by carbon flakes as a high performance sodium storage anode. J. Mater. Chem. A 2017, 5, 1160. [CrossRef] 
108. Liu, S.; Cai, Z.; Zhou, J.; Zhu, M.; Pan, A.; Liang, S. High-performance sodium-ion batteries and flexible sodium-ion capacitors based on $\mathrm{Sb}_{2 \times 3}(\mathrm{X}=\mathrm{O}, \mathrm{S}) /$ carbon fiber cloth. J. Mater. Chem. A 2017, 5, 9169-9176. [CrossRef]

109. Kalubarme, R.S.; Park, C.-J.; Kale, B.B.; Gosavi, S.W. Highly crystalline antimony oxide octahedron: An efficient anode for sodium-ion batteries. J. Mater. Sci. Mater. Electron. 2021, 32, 3809-3818. [CrossRef]

110. Chen, X.Y.; Huh, H.S.; Lee, S.W. Hydrothermal synthesis of antimony oxychloride and oxide nanocrystals: $\mathrm{Sb}_{4} \mathrm{O}_{5} \mathrm{Cl}_{2}, \mathrm{Sb}_{8} \mathrm{O}_{11} \mathrm{Cl}_{2}$, and $\mathrm{Sb}_{2} \mathrm{O}$. J. Solid State Chem. 2008, 181, 2127-2132. [CrossRef]

111. Lin, Y.; Feng, W.; Li, Z.; Xu, T.; Fei, H. Facile synthesis of phase-pure $\mathrm{Sb}_{8} \mathrm{O}_{11} \mathrm{Cl}_{2}$ microrods as anode materials for sodium-ion batteries with high capacity. Ionics 2017, 23, 3197-3202. [CrossRef]

112. Xie, J.; Pei, Y.; Liu, L.; Guo, S.-P.; Xia, J.; Li, M.; Ouyang, Y.; Zhang, X.; Wang, X. Hydrothermal synthesis of antimony oxychlorides submicron rods as anode materials for lithium-ion batteries and sodium-ion batteries. Electrochim. Acta 2017, 254, 246-254. [CrossRef]

113. Tang, J.-J.; Wang, Y.; Jiao, Z.; Wu, M. Self-assembly nanostructures of one-dimensional antimony oxide and oxychloride. Mater. Lett. 2009, 63, 1481-1484. [CrossRef]

114. Zhou, J.; Zhao, H.; Li, L.; Tian, M.; Han, J.; Zhang, L.; Guo, L. One-step synthesis and flame retardancy of sheaf-like microcrystal antimony oxychloride. J. Nanosci. Nanotechnol. 2011, 11, 8504-8509. [CrossRef] [PubMed]

115. Lakshmi, K.; Janas, K.; Shaijumon, M. Antimony oxychloride/graphene aerogel composite as anode material for sodium and lithium ion batteries. Carbon 2018, 131, 86-93. [CrossRef]

116. Li, M.; Liu, Y.; Qin, B.; Lu, C.; Butt, H.A.; Zheng, T.; Zhang, D. Polyaniline-coated nanoporous antimony with improved performance for sodium-ion battery anodes. J. Alloy. Compd. 2021, 861, 158647. [CrossRef]

117. Luo, X.; Tan, H.; Ma, T.; Wang, H.; Lv, M.; Yu, Z.; Fu, C.; Chang, X.; Jin, S. Nitrogen doped porous carbon coated antimony as high performance anode material for sodium-ion batteries. Nanotechnology 2021, 32, 315401. [CrossRef] [PubMed]

118. Xie, H.; Kalisvaart, W.P.; Olsen, B.C.; Luber, E.J.; Mitlin, D.; Buriak, J.M. Sn-Bi-Sb alloys as anode materials for sodium ion batteries. J. Mater. Chem. A 2017, 5, 9661-9670. [CrossRef]

119. Zhao, Y.; Manthiram, A. High-Capacity, High-Rate Bi-Sb Alloy Anodes for Lithium-Ion and Sodium-Ion Batteries. Chem. Mater. 2015, 27, 3096-3101. [CrossRef]

120. Yu, D.-K.; Park, C.-M. Sb-based intermetallics and nanocomposites as stable and fast Na-ion battery anodes. Chem. Eng. J. 2021, 409, 127380. [CrossRef]

121. Guo, S.; Li, H.; Lu, Y.; Liu, Z.; Hu, X. Lattice softening enables highly reversible sodium storage in anti-pulverization Bi-Sb alloy/carbon nanofibers. Energy Storage Mater. 2020, 27, 270-278. [CrossRef]

122. Kalisvaart, W.P.; Xie, H.; Olsen, B.C.; Luber, E.J.; Buriak, J.M. Understanding the Mechanism of Enhanced Cycling Stability in Sn-Sb Composite Na-Ion Battery Anodes: Operando Alloying and Diffusion Barriers. ACS Appl. Energy Mater. 2019, 2, 5133-5139. [CrossRef]

123. Sarkar, S.; Peter, S.C. An overview on Sb-based intermetallics and alloys for sodium-ion batteries: Trends, challenges and future prospects from material synthesis to battery performance. J. Mater. Chem. A 2021, 9, 5164-5196. [CrossRef]

124. Xie, H.; Tan, X.; Luber, E.J.; Olsen, B.C.; Kalisvaart, W.P.; Jungjohann, K.L.; Mitlin, D.; Buriak, J.M. $\beta$-SnSb for Sodium Ion Battery Anodes: Phase Transformations Responsible for Enhanced Cycling Stability Revealed by In Situ TEM. ACS Energy Lett. 2018, 3 , 1670-1676. [CrossRef]

125. Sarkar, S.; Chaupatnaik, A.; Ramarao, S.D.; Subbarao, U.; Barpanda, P.; Peter, S.C. Operando Sodiation Mechanistic Study of a New Antimony-Based Intermetallic CoSb as a High-Performance Sodium-Ion Battery Anode. J. Phys. Chem. C 2020, 124, 15757-15768. [CrossRef]

126. Li, C.; Pei, Y.R.; Zhao, M.; Yang, C.C.; Jiang, Q. Sodium storage performance of ultrasmall SnSb nanoparticles. Chem. Eng. J. 2021, 420, 129617. [CrossRef]

127. Luo, W.; Calas, A.; Tang, C.; Li, F.; Zhou, L.; Mai, L. Ultralong $\mathrm{Sb}_{2} \mathrm{Se}_{3}$ Nanowire-Based Free-Standing Membrane Anode for Lithium/Sodium Ion Batteries. ACS Appl. Mater. Interfaces 2016, 8, 35219-35226. [CrossRef] [PubMed]

128. Luo, W.; Li, F.; Li, Q.; Wang, X.; Yang, W.; Zhou, L.; Mai, L. Heterostructured $\mathrm{Bi}_{2} \mathrm{~S}_{3}-\mathrm{Bi}_{2} \mathrm{O}_{3}$ Nanosheets with a Built-In Electric Field for Improved Sodium Storage. ACS Appl. Mater. Interfaces 2018, 10, 7201-7207. [CrossRef]

129. Kravchyk, K.V.; Kovalenko, M.V.; Bodnarchuk, M.I. Colloidal Antimony Sulfide Nanoparticles as a High-Performance Anode Material for Li-ion and Na-ion Batteries. Sci. Rep. 2020, 10, 2554. [CrossRef]

130. Choi, J.-H.; Lee, M.-H.; Choi, H.-Y.; Park, C.-M.; Lee, S.-M.; Choi, J.-H. Investigation of electrochemical reaction mechanism for antimony selenide nanocomposite for sodium-ion battery electrodes. J. Appl. Electrochem. 2018, 49, 207-216. [CrossRef]

131. Ge, P.; Cao, X.-Y.; Hou, H.; Li, S.; Ji, X. Rodlike $\mathrm{Sb}_{2} \mathrm{Se}_{3}$ Wrapped with Carbon: The Exploring of Electrochemical Properties in Sodium-Ion Batteries. ACS Appl. Mater. Interfaces 2017, 9, 34979-34989. [CrossRef] [PubMed]

132. Nam, K.-H.; Park, C.-M. 2D layered $\mathrm{Sb}_{2} \mathrm{Se}_{3}$-based amorphous composite for high-performance Li- and Na-ion battery anodes. $J$. Power Sources 2019, 433, 126639. [CrossRef]

133. Wen, J.; Pei, Y.; Liu, L.; Su, D.; Yang, M.; Wang, Q.; Zhang, W.; Dai, J.; Feng, Y.; Wu, T.; et al. Fully encapsulated Sb $\mathrm{Se}_{3} / \mathrm{Sb}_{\mathrm{C}} \mathrm{C}$ nanofibers: Towards high-rate, ultralong-lifespan lithium-ion batteries. J. Alloy. Compd. 2021, 874, 159961. [CrossRef]

134. Guo, L.; Cao, L.; Huang, J.; Li, J.; Chen, S. Carbon capsule confined $\mathrm{Sb}_{2} \mathrm{Se}_{3}$ for fast $\mathrm{Na}+$ extraction in sodium-ion batteries. Sustain. Energy Fuels 2020, 4, 797-808. [CrossRef] 
135. Zhai, H.; Jiang, H.; Qian, Y.; Cai, X.; Liu, H.; Qiu, Y.; Jin, M.; Xiu, F.; Liu, X.; Lai, L. Sb ${ }_{2} \mathrm{~S}_{3}$ nanocrystals embedded in multichannel $\mathrm{N}$-doped carbon nanofiber for ultralong cycle life sodium-ion batteries. Mater. Chem. Phys. 2020, 240, 122139. [CrossRef]

136. Wen, S.; Zhao, J.; Zhao, Y.; Xu, T.; Xu, J. Reduced graphene oxide (RGO) decorated $\mathrm{Sb}_{2} \mathrm{~S}_{3}$ nanorods as anode material for sodium-ion batteries. Chem. Phys. Lett. 2019, 716, 171-176. [CrossRef]

137. Zhang, Q.; Zeng, Y.; Wang, X.; Wang, L.; Wang, H.; Xiao, J.; Li, X. Sb $\mathrm{S}_{3}$ nanoparticles anchored on N-doped 3D carbon nanofibers as anode material for sodium ion batteries with improved electrochemical performance. J. Alloy. Compd. 2021, 881, 160594. [CrossRef]

138. Ge, P.; Hou, H.; Ji, X.; Huang, Z.; Li, S.; Huang, L. Enhanced stability of sodium storage exhibited by carbon coated $\mathrm{Sb}_{2} \mathrm{~S}_{3}$ hollow spheres. Mater. Chem. Phys. 2018, 203, 185-192. [CrossRef]

139. Dashairya, L.; Das, D.; Saha, P. Elucidating the role of graphene and porous carbon coating on nanostructured $\mathrm{Sb}_{2} \mathrm{~S}_{3}$ for superior lithium and sodium storage. J. Alloy. Compd. 2021, 883, 160906. [CrossRef]

140. Hameed, A.S.; Reddy, M.V.; Chen, J.L.T.; Chowdari, B.V.R.; Vittal, J.J. RGO/Stibnite Nanocomposite as a Dual Anode for Lithium and Sodium Ion Batteries. ACS Sustain. Chem. Eng. 2016, 4, 2479-2486. [CrossRef]

141. Guo, L.; Cao, L.; Huang, J.; Wang, Y.; Li, W.; Qi, H.; Chen, S.; Li, J. Design of an ultra-stable $\mathrm{Sb}_{2} \mathrm{Se}_{3}$ anode with excellent Na storage performance. J. Alloys Compd. 2019, 810, 151930. [CrossRef]

142. Zheng, T.; Li, G.; Zhao, L.; Shen, Y. Flowerlike $\mathrm{Sb}_{2} \mathrm{~S}_{3}$ /PPy Microspheres Used as Anode Material for High-Performance SodiumIon Batteries. Eur. J. Inorg. Chem. 2018, 2018, 1224-1228. [CrossRef]

143. Shi, Y.; Li, F.; Zhang, Y.; He, L.; Ai, Q.; Luo, W. Sb $2 \mathrm{~S}_{3} @ P P y$ Coaxial Nanorods: A Versatile and Robust Host Material for Reversible Storage of Alkali Metal Ions. Nanomaterials 2019, 9, 560. [CrossRef]

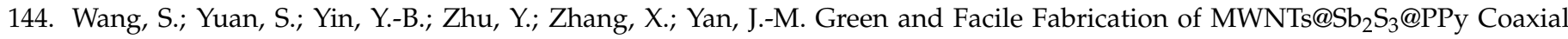
Nanocables for High-Performance Na-Ion Batteries. Part. Part. Syst. Charact. 2016, 33, 493-499. [CrossRef]

145. Pan, Z.-Z.; Yan, Y.; Cui, N.; Xie, J.-C.; Zhang, Y.-B.; Mu, W.-S.; Hao, C. Ionic Liquid-Assisted Preparation of $\mathrm{Sb}_{2} \mathrm{~S}_{3} / \mathrm{Reduced}$ Graphene Oxide Nanocomposite for Sodium-Ion Batteries. Adv. Mater. Interfaces 2018, 5, 1701481. [CrossRef]

146. Luo, W.; Gaumet, J.-J.; Magri, P.; Diliberto, S.; Li, F.; Franchetti, P.; Ghanbaja, J.; Mai, L. Fast, green microwave-assisted synthesis of single crystalline $\mathrm{Sb}_{2} \mathrm{Se}_{3}$ nanowires towards promising lithium storage. J. Energy Chem. 2019, 30, 27-33. [CrossRef]

147. Yao, S.; Cui, J.; Deng, Y.; Chong, W.G.; Wu, J.; Haq, M.I.U.; Mai, Y.-W.; Kim, J.-K. Ultrathin $\mathrm{Sb}_{2} \mathrm{~S}_{3}$ nanosheet anodes for exceptional pseudocapacitive contribution to multi-battery charge storage. Energy Storage Mater. 2019, 20, 36-45. [CrossRef]

148. Hou, H.; Jing, M.; Huang, Z.; Yang, Y.; Zhang, Y.; Chen, J.; Wu, Z.; Ji, X. One-Dimensional Rod-Like Sb ${ }_{2} \mathrm{~S}_{3}$-Based Anode for High-Performance Sodium-Ion Batteries. ACS Appl. Mater. Interfaces 2015, 7, 19362-19369. [CrossRef] [PubMed]

149. Li, J.; Yan, D.; Zhang, X.; Hou, S.; Li, D.; Lu, T.; Yao, Y.; Pan, L. In situ growth of $\mathrm{Sb}_{2} \mathrm{~S}_{3}$ on multiwalled carbon nanotubes as high-performance anode materials for sodium-ion batteries. Electrochim. Acta 2017, 228, 436-446. [CrossRef]

150. Xie, J.; Xia, J.; Yuan, Y.; Liu, L.; Zhang, Y.; Nie, S.; Yan, H.; Wang, X. $\mathrm{Sb}_{2} \mathrm{~S}_{3}$ embedded in carbon-silicon oxide nanofibers as high-performance anode materials for lithium-ion and sodium-ion batteries. J. Power Sources 2019, 435, 226762. [CrossRef]

151. Xia, L.; Yang, Z.; Tang, B.; Li, F.; Wei, J.; Zhou, Z. Carbon Nanofibers with Embedded $\mathrm{Sb}_{2} \mathrm{Se}_{3}$ Nanoparticles as Highly Reversible Anodes for Na-Ion Batteries. Small 2021, 17, e2006016. [CrossRef] [PubMed]

152. Dong, Y.; Hu, M.; Zhang, Z.; Zapien, J.A.; Wang, X.; Lee, J.-M.; Zhang, W. Nitrogen-Doped Carbon-Encapsulated Antimony Sulfide Nanowires Enable High Rate Capability and Cyclic Stability for Sodium-Ion Batteries. ACS Appl. Nano Mater. 2019, 2, 1457-1465. [CrossRef]

153. Jiang, Q.; Zhang, W.-Q.; Zhao, J.-C.; Rao, P.-H.; Mao, J.-F. Superior sodium and lithium storage in strongly coupled amorphous Sb2S3 spheres and carbon nanotubes. Int. J. Miner. Met. Mater. 2021, 28, 1194-1203. [CrossRef]

154. Zhao, W.; Li, M.; Qi, Y.; Tao, Y.; Shi, Z.; Liu, Y.; Cheng, J. Ultrasound sonochemical synthesis of amorphous $\mathrm{Sb}_{2} \mathrm{~S}_{3}-\mathrm{graphene}$ composites for sodium-ion batteries. J. Colloid Interface Sci. 2021, 586, 404-411. [CrossRef]

155. Li, M.; Huang, F.; Pan, J.; Li, L.; Zhang, Y.; Yao, Q.; Zhou, H.; Deng, J. Amorphous $\mathrm{Sb}_{2} \mathrm{~S}_{3}$ Nanospheres In-Situ Grown on Carbon Nanotubes: Anodes for NIBs and KIBs. Nanomater. 2019, 9, 1323. [CrossRef]

156. Zhao, Y.; Manthiram, A. Amorphous $\mathrm{Sb}_{2} \mathrm{~S}_{3}$ embedded in graphite: A high-rate, long-life anode material for sodium-ion batteries Chem. Commun. 2015, 51, 13205-13208. [CrossRef] [PubMed]

157. Fang, Y.; Yu, X.; Wen, X. Formation of Polypyrrole-Coated $\mathrm{Sb}_{2} \mathrm{Se}_{3}$ Microclips with Enhanced Sodium-Storage Properties. Angew. Chem. Int. Ed. 2018, 57, 9859-9863. [CrossRef] [PubMed]

158. Xie, F.; Zhang, L.; Gu, Q.; Chao, D.; Jaroniec, M.; Qiao, S.Z. Multi-shell hollow structured $\mathrm{Sb}_{2} \mathrm{~S}_{3}$ for sodium-ion batteries with enhanced energy density. Nano Energy 2019, 60, 591-599. [CrossRef]

159. Cao, L.; Gao, X.; Zhang, B.; Ou, X.; Zhang, J.; Luo, W.-B. Bimetallic Sulfide $\mathrm{Sb}_{2} \mathrm{~S}_{3} @ \mathrm{FeS}_{2}$ Hollow Nanorods as High-Performance Anode Materials for Sodium-Ion Batteries. ACS Nano 2020, 14, 3610-3620. [CrossRef]

160. Wang, Y.; Cao, D.; Zhang, K.; Kang, W.; Wang, X.; Ma, P.; Wan, Y.; Cao, D.; Sun, D. Cation-exchange construction of ZnSe/Sb $2 \mathrm{Se}_{3}$ hollow microspheres coated by nitrogen-doped carbon with enhanced sodium ion storage capability. Nanoscale 2020, 12, 17915-17924. [CrossRef] [PubMed]

161. Dong, S.; Li, C.; Ge, X.; Li, Z.; Miao, X.; Yin, L. ZnS-Sb $2 \mathrm{~S}_{3} @ C$ Core-Double Shell Polyhedron Structure Derived from Metal-Organic Framework as Anodes for High Performance Sodium Ion Batteries. ACS Nano 2017, 11, 6474-6482. [CrossRef] [PubMed]

162. Xia, J.; Zhang, X.; Yang, Y.; Wang, X.; Yao, J. Electrospinning fabrication of flexible, foldable, and twistable $\mathrm{Sb}_{2} \mathrm{~S}_{3} / \mathrm{TiO}_{2} / \mathrm{C}$ nanofiber anode for lithium ion batteries. Chem. Eng. J. 2021, 413, 127400. [CrossRef] 
163. Xiong, X.; Wang, G.; Lin, Y.; Wang, Y.; Ou, X.; Zheng, F.; Yang, C.; Wang, J.-H.; Liu, M. Enhancing Sodium Ion Battery Performance by Strongly Binding Nanostructured $\mathrm{Sb}_{2} \mathrm{~S}_{3}$ on Sulfur-Doped Graphene Sheets. ACS Nano 2016, 10, 10953-10959. [CrossRef]

164. Zhao, W.; Li, C.M. Mesh-structured N-doped graphene@Sb ${ }_{2} \mathrm{Se}_{3}$ hybrids as an anode for large capacity sodium-ion batteries. J. Colloid Interface Sci. 2017, 488, 356-364. [CrossRef] [PubMed]

165. Chang, G.; Yin, X.; Shi, S.; Zhao, Y.; Zhang, J. Sb ${ }_{2} \mathrm{~S}_{3} @ Y P$ Nanostructured Anode Material Synthesized by a Novel VaporizationCondensation Method for Long Cycle-Life Sodium-Ion Battery. J. Electrochem. Soc. 2020, 167, 140531. [CrossRef]

166. Jaramillo-Quintero, O.A.; Barrera-Peralta, R.V.; El Hachimi, A.G.; Guillén-López, A.; Pérez, O.; Reguera, E.; Rincón, M.E.; Muñiz, J. Understanding the interaction between heteroatom-doped carbon matrix and $\mathrm{Sb}_{2} \mathrm{~S}_{3}$ for efficient sodium-ion battery anodes. $J$. Colloid Interface Sci. 2021, 585, 649-659. [CrossRef]

167. Zhan, W.; Zhu, M.; Lan, J.; Wang, H.; Yuan, H.; Yang, X.; Sui, G. 1D Sb $2 \mathrm{~S}_{3} @$ nitrogen-doped carbon coaxial nanotubes uniformly encapsulated within 3D porous graphene aerogel for fast and stable sodium storage. Chem. Eng. J. 2021, 408, 128007. [CrossRef]

168. El Hachimi, A.G.; Guillén-López, A.; Jaramillo-Quintero, O.A.; Rincón, M.E.; Sevilla-Camacho, P.Y.; Muñiz, J. Exploring the enhanced performance of $\mathrm{Sb}_{2} \mathrm{~S}_{3}$ /doped-carbon composites as potential anode materials for sodium-ion batteries: A density functional theory approach. Int. J. Quantum Chem. 2021, 121, e26779. [CrossRef]

169. He, F.; Tang, C.; Zhu, G.; Liu, Y.; Du, A.; Zhang, Q.; Wu, M.; Zhang, H. Leaf-inspired design of mesoporous Sb2S3/N-doped $\mathrm{Ti}_{3} \mathrm{C}_{2} \mathrm{Tx}$ composite towards fast sodium storage. Sci. China Ser. B Chem. 2021, 64, 964-973. [CrossRef]

170. Wu, Y.; Nie, P.; Dou, H.; Jiang, J.; Zhu, Y.; Zhang, X. Graphene scrolls coated $\mathrm{Sb}_{2} \mathrm{~S}_{3}$ nanowires as anodes for sodium and lithium ion batteries. Nano-Struct. Nano-Objects 2018, 15, 197-204. [CrossRef]

171. Wang, D.; Cao, L.; Luo, D.; Gao, R.; Li, H.; Wang, D.; Sun, G.; Zhao, Z.; Li, N.; Zhang, Y.; et al. Chain mail heterostructured hydrangea-like binary metal sulfides for high efficiency sodium ion battery. Nano Energy 2021, 87, 106185. [CrossRef]

172. Li, K.; Liu, X.; Qin, Y.; Zhao, Z.; Xu, Y.; Yi, Y.; Guan, H.; Fu, Y.; Liu, P.; Li, D. $\mathrm{Sb}_{2} \mathrm{~S}_{3}-\mathrm{Bi}_{2} \mathrm{~S}_{3}$ microrods with the combined action of carbon encapsulation and rGO confinement for improving high cycle stability in sodium/potassium storage. Chem. Eng. J. 2021, 414, 128787. [CrossRef]

173. Lin, J.; Yao, L.; Zhang, C.; Ding, H.; Wu, Y.; Li, S.; Han, J.; Yue, G.; Peng, D. Construction of Sb ${ }_{2} \mathrm{~S}_{3} @ S$ SnS@C Tubular Heterostructures as High-Performance Anode Materials for Sodium-Ion Batteries. ACS Sustain. Chem. Eng. 2021, 9, 11280-11289. [CrossRef]

174. Zhang, Z.; Zhao, J.; Xu, M.; Wang, H.; Gong, Y.; Xu, J. Facile synthesis of $\mathrm{Sb}_{2} \mathrm{~S}_{3} / \mathrm{MoS}_{2}$ heterostructure as anode material for sodium-ion batteries. Nanotechnol. 2018, 29, 335401. [CrossRef]

175. Bera, S.; Roy, A.; Guria, A.K.; Mitra, S.; Pradhan, N. Insights of Diffusion Doping in Formation of Dual-Layered Material and Doped Heterostructure SnS-Sn:Sb ${ }_{2} \mathrm{~S}_{3}$ for Sodium Ion Storage. J. Phys. Chem. Lett. 2019, 10, 1024-1030. [CrossRef]

176. Li, X.; Liang, H.; Liu, X.; Sun, R.; Qin, Z.; Fan, H.; Zhang, Y. Ion-exchange strategy of $\mathrm{CoS}_{2} / \mathrm{Sb}_{2} \mathrm{~S}_{3}$ hetero-structured nanocrystals encapsulated into 3D interpenetrating dual-carbon framework for high-performance $\mathrm{Na}^{+} / \mathrm{K}^{+}$batteries. Chem. Eng. J. 2021, 425, 130657. [CrossRef]

177. Yan, C.; Zhu, Y.; Li, Y.; Fang, Z.; Peng, L.; Zhou, X.; Chen, G.; Yu, G. Local Built-In Electric Field Enabled in Carbon-Doped Co ${ }_{3} \mathrm{O}_{4}$ Nanocrystals for Superior Lithium-Ion Storage. Adv. Funct. Mater. 2018, 28, 166-173. [CrossRef]

178. Zheng, Y.; Zhou, T.; Zhao, X.; Pang, W.K.; Gao, H.; Li, S.; Zhou, Z.; Liu, H.K.; Guo, Z. Atomic Interface Engineering and Electric-Field Effect in Ultrathin $\mathrm{Bi}_{2} \mathrm{MoO}_{6}$ Nanosheets for Superior Lithium Ion Storage. Adv. Mater. 2017, 29, 1700396. [CrossRef]

179. Wang, S.; Liu, S.; Li, X.; Li, C.; Zang, R.; Man, Z.; Wu, Y.; Li, P.; Wang, G. $\mathrm{SnS}_{2} / \mathrm{Sb}_{2} \mathrm{~S}_{3}$ Heterostructures Anchored on Reduced Graphene Oxide Nanosheets with Superior Rate Capability for Sodium-Ion Batteries. Chem.-A Eur. J. 2018, 24, $3873-3881$. [CrossRef]

180. Ren, M.; Cao, D.; Jiang, W.; Su, K.; Pan, L.; Jiang, Y.; Yan, S.; Qiu, T.; Yang, M.; Yang, J.; et al. Hierarchical Composite of Sb ${ }_{2} \mathrm{~S}_{3}$ decorated on highly crumpled $\mathrm{Ti}_{3} \mathrm{C}_{2} \mathrm{Tx}$ nanosheets for enhanced sodium storage properties. Electrochim. Acta 2021, $373,137835$. [CrossRef]

181. Zhang, H.; Ren, M.; Jiang, W.; Yao, J.; Pan, L.; Yang, J. Hierarchical $\mathrm{Sb}_{2} \mathrm{~S}_{3} @ \mathrm{~m}-\mathrm{Ti}_{3} \mathrm{C}_{2} \mathrm{Tx}$ composite anode with enhanced Na-ion storage properties. J. Alloy. Compd. 2021, 887, 161318. [CrossRef]

182. Ihsan-Ul-Haq, M.; Huang, H.; Wu, J.; Mubarak, N.; Susca, A.; Luo, Z.; Huang, B.; Kim, J.-K. Unveiling solid electrolyte interface morphology and electrochemical kinetics of amorphous $\mathrm{Sb}_{2} \mathrm{Se}_{3} / \mathrm{CNT}$ composite anodes for ultrafast sodium storage. Carbon 2021, 171, 119-129. [CrossRef]

183. Ma, X.; Luo, W.; Yan, M.; He, L.; Mai, L. In situ characterization of electrochemical processes in one dimensional nanomaterials for energy storages devices. Nano Energy 2016, 24, 165-188. [CrossRef]

184. Yao, S.; Cui, J.; Lu, Z.; Xu, Z.-L.; Qin, L.; Huang, J.; Sadighi, Z.; Ciucci, F.; Kim, J.-K. Unveiling the Unique Phase Transformation Behavior and Sodiation Kinetics of 1D van der Waals Sb2S3Anodes for Sodium Ion Batteries. Adv. Energy Mater. $2017,7,1602149$. [CrossRef]

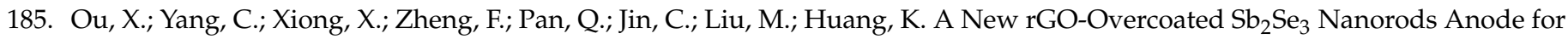
$\mathrm{Na}+$ Battery: In Situ X-Ray Diffraction Study on a Live Sodiation/Desodiation Process. Adv. Funct. Mater. 2017, $27,1606242$. [CrossRef]

186. Wu, Y.; Luo, W.; Gao, P.; Zhu, C.; Hu, X.; Qu, K.; Chen, J.; Wang, Y.; Sun, L.; Mai, L.; et al. Unveiling the microscopic origin of asymmetric phase transformations in (de)sodiated $\mathrm{Sb}_{2} \mathrm{Se}_{3}$ with in situ transmission electron microscopy. Nano Energy 2020, 77, 105299. [CrossRef] 